\title{
Application of Bacteriophages in Nanotechnology
}

\author{
Jan Paczesny *(i) and Krzysztof Bielec(i) \\ Institute of Physical Chemistry of the Polish Academy of Sciences, Kasprzaka 44/52, 01-224 Warsaw, Poland; \\ kbielec@ichf.edu.pl \\ * Correspondence: jpaczesny@ichf.edu.pl; Tel.: +48-22-343-2071
}

Received: 27 August 2020; Accepted: 27 September 2020; Published: 29 September 2020

\begin{abstract}
Bacteriophages (phages for short) are viruses, which have bacteria as hosts. The single phage body virion, is a colloidal particle, often possessing a dipole moment. As such, phages were used as perfectly monodisperse systems to study various physicochemical phenomena (e.g., transport or sedimentation in complex fluids), or in the material science (e.g., as scaffolds). Nevertheless, phages also execute the life cycle to multiply and produce progeny virions. Upon completion of the life cycle of phages, the host cells are usually destroyed. Natural abilities to bind to and kill bacteria were a starting point for utilizing phages in phage therapies (i.e., medical treatments that use phages to fight bacterial infections) and for bacteria detection. Numerous applications of phages became possible thanks to phage display-a method connecting the phenotype and genotype, which allows for selecting specific peptides or proteins with affinity to a given target. Here, we review the application of bacteriophages in nanoscience, emphasizing bio-related applications, material science, soft matter research, and physical chemistry.
\end{abstract}

Keywords: bacteriophages; phage display; phage therapies; phage-based sensors; soft matter; materials; scaffolds; viruses

\section{Introduction}

Nanoscience is "enabling technology", which impacts numerous fields of research and everyday life. The socio-economic implications of introducing new nanotechnology or a class of nanomaterials can be, therefore, far-reaching (across many economic sectors) and very deep (starting at the beginning of the value/supply chain) [1]. The most widely used in the industry is the "top-down" approach for the preparation of nano-objects. "Top-down" utilizes external tools and forces the creation of smaller objects from larger entities (via e.g., milling, lithography, printing). It seems that the developments in the field are reaching their limit, with Intel not being able to master a $7 \mathrm{~nm}$ process for many years now [2]. Alternatively, in the "bottom-up" approach, individual parts self-assemble spontaneously to form ordered and/or functional structures due to specific interactions, often imposed on these building blocks. Despite all the advances that nanotechnology has brought to us, the abiotic self-assembling systems are relatively simple, and their functionalities are restricted. Even with the introduction of dynamic self-assembly, which allowed to design systems consuming energy to maintain their structure and functions [3], and some advantages in creating chemical networks [4], we are still far behind the level of complexity present in nature. Nevertheless, we have learned to take advantage of biotic functional systems and incorporate some "natural" building blocks into human-made nanodesigns. Here, we review the specific manifestation of such an approach, namely the utilization of bacteriophages (phages for short), i.e., viruses, which have bacteria as hosts.

The average size of the virion, i.e., a single phage body, is around $30-200 \mathrm{~nm}$, but the largest might be more than $800 \mathrm{~nm}$ in length [5]. The most popular phages fit perfectly into the category of nano-objects, i.e., having at least one geometrical dimension smaller than $100 \mathrm{~nm}$. Nature offers a 
great variety of the possible structural morphologies of phages. The majority belong to the order of Caudovirales and share a typical structure design, i.e., the genetic information is stored in a capsid, to which a spike-tail with fibers is attached [6,7]. Less common are filamentous (e.g., M13) or nearly spherical (isometric) phages (e.g., MS2). Filamentous phages are broadly used, as they are most robust in phage display (cf. Section 2.1), and they form liquid crystalline phases (cf. Section 4). MS2 is used as a model of eukaryotic viruses in a number of bio-related studies [8]. T1, T4, T7, or Lambda phages are the most well known examples of tailed phages and are often chosen as model systems representing the most abundant Caudovirales order. It is estimated that there are around $10^{31}$ phages on the planet, making them the most abundant and diverse biological entities. They have a profound role as modulators in numerous biomes, ranging from the human gut to biogeochemical cycling in aquatic environments [7].

Phages can be produced easily and cheaply in large quantities and easily purified. By only infecting a bacteria solution, one can obtain a large number of progeny phages. Phages undergo evolution, and thus they remain effective against bacteria [9]. For example, anti-CRISPR (Anti-Clustered Regularly Interspaced Short Palindromic Repeats) [10] mechanism was discovered shortly after CRISPR [11]—a molecular mechanism that allows bacteria to recognize and degrade alien genetic material. Some phages are robust and retain their activity even after exposure to high temperatures [12], $\mathrm{pH}$ [13], and organic solvents [14,15]. Each virion of a given phage is identical (no polydispersity of sizes), whereas chemical and genetic modifications allow for the preparation of the virions of desired properties. All these traits make phages exciting building blocks for utilization in nanotechnology.

\section{Bacteriophages in Bio-Related Applications}

Phages attach to the host cell and introduce genetic materials inside bacteria. What happens next determines the qualification of bacteriophages as a lysogenic and lytic one (see Figure 1A). In the lytic cycle, a host's cell is disrupted to free progeny phages from the infected bacteria. Lysis is possible due to the amurins, which are proteins that inhibit peptidoglycan synthesis [16]. In the lysogenic cycle, the viral genome integrates into the chromosome of bacteria and remains latent, replicating for generations [17]. When viral genetic material is incorporated into the chromosomal DNA of bacteria, it is known as a prophage [18]. The appearance of stressors, e.g., chemicals, UV radiation, or damage of the host DNA, can cause the conversion of the cycle and change from lysogenic into the lytic [19]. Only some filamentous phages might cause the continuous generation of progeny virions without causing the death of the host [20]. Bacteriophages are considered non-toxic to eukaryotes because structural elements of the virion cannot bind to eukaryotic cells [21].

\subsection{Phage Display and Phage-Based Delivery Systems}

One half of the 2018 Nobel Prize in Chemistry was awarded to George P. Smith and Sir Gregory P. Winter "for the phage display of peptides and antibodies" [22]. The method utilizes the possibility to genetically modify phages to display peptides, proteins, or antibodies at the surface via fusion with appropriate gene product. This results in a connection between genotype and phenotype. The exposition of phages possessing various inserts to a target material allows for the screening of large libraries in search of peptides or even proteins that interact with the target. Bio-panning allows for selecting specific peptides or proteins with affinity to a given target (see Figure 1B). Biopanning involves four major steps: (1) the preparation of phage display libraries, (2) capturing steps, where virions displaying sequence having affinity to the target bind to it, (3) washing step, which removes unbound virions, and (4) the elution step, which allows collecting phages with specific affinity. In the earliest examples, genes were cloned directly into the phage genome. Alternatively, phagemid vectors are used; in such a case, "helper phage" is needed to produce functional virions. The M13 phage, and the closely related fd and f1, are the most extensively used in phage display [23]. 
A

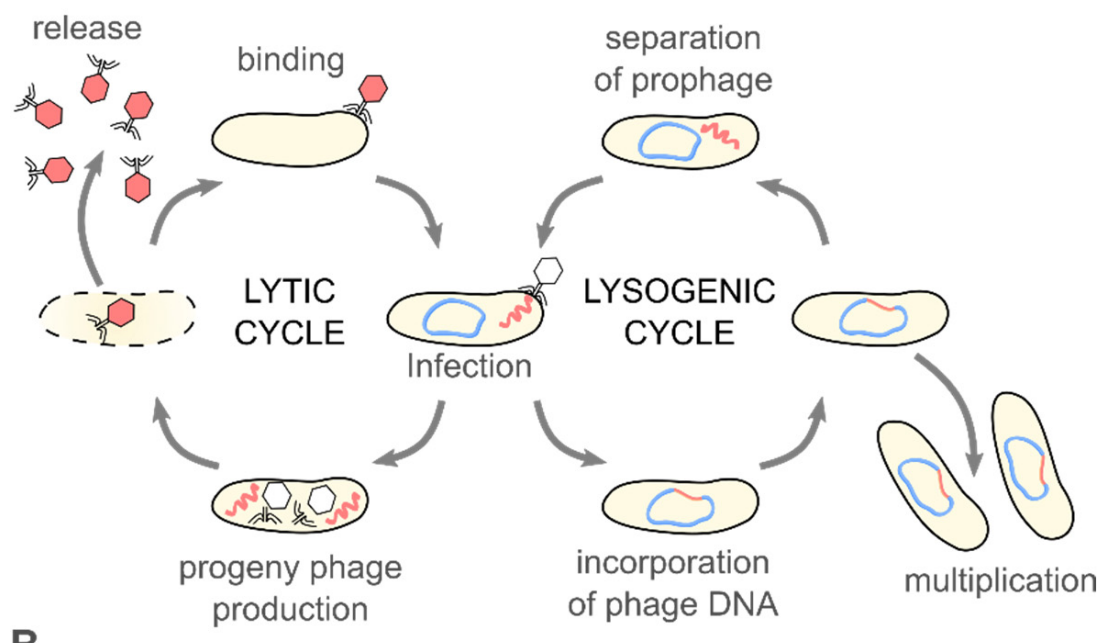

B

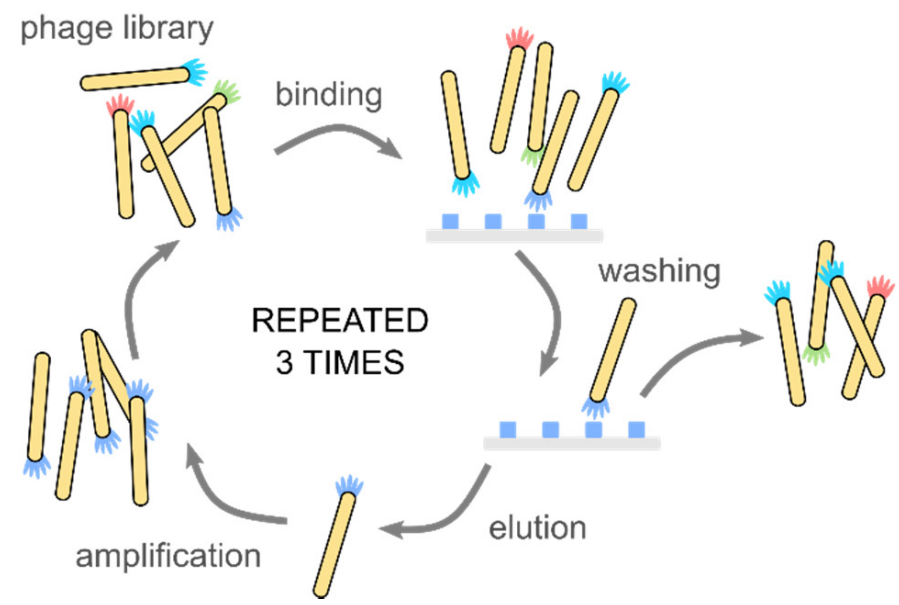

Figure 1. (A) Bacteriophages are obligate parasites, which usurp the molecular machinery of the host to complete their life cycle. First, phage virions bind to target bacteria and inject the genetic information into the host cell. Only the recognition of a proper host assures the completion of the cycle. In the case of lytic phages, progeny virions are produced inside the host cell. The release of the progeny virions usually results in the disruption and death of the bacterium. Temperate phages integrate their genetic information with the genome of the host, forming a prophage. A prophage replicates upon divisions of the bacteria. External stimuli (e.g., food shortage, UV light, temperature) might activate the prophage, and thus start the lytic cycle. These natural mechanisms (i.e., binding to specific target bacteria and amplification), along with the monodispersity of virions and a variety of morphologies, are fundamental for the application of phages in phage therapies, biocontrol, sensing, material science, and soft matter research. (B) The discovery of the phage display method significantly broadened the possible usage of bacteriophage. In the phage display, a fusion of large libraries with genes coding coat proteins allows for a direct correlation between the genome and phenotype. Bio-panning allows for selecting specific peptides or proteins with affinity to a given target. These selected peptides might be used separately or provide phage virions with additional functionalities. Phage display was crucial in the development of new drugs, vaccines, but also material science and physical chemistry.

The possibility to probe and identify ligand-receptor interactions allowed for advancement in studies of infectious diseases [24] and cancer [25,26]. This resulted in improvements in drug discovery and vaccine design [27]. The overview of the phage-display method and its utilization in medicine can be found in recent reviews by Mimmi et al. [28], Sokullu et al. [29], Petrenko [30], Garg [31], Sunderland et al. [32], and Newman and Benoit [33]. 
In a new example by Lauster and coworkers [34], the modification of a phage capsid with non-natural amino acid (L-homopropargylglycine) was introduced to the coat protein for spatial control over the distribution of ligands binding to the spike protein of the influenza A virus. The appropriate geometrical distribution of ligands was possible due to the symmetric, icosahedral structure of bacteriophages $\mathrm{Q} \beta$. These capsids bind to the influenza A virus envelope in the multivalent mode, thus inhibiting the infection of eukaryotic cells.

Not only medicine but also nanotechnology are taking advantage of the phage-display technique. There are examples of phage display-selected peptides for the binding of nanoparticles (e.g., noble metals [35], $\mathrm{ZnO}$ [36], $\mathrm{Fe}_{3} \mathrm{O}_{4}$ [37,38], semiconductors $\mathrm{TiO}_{2}, \mathrm{CdS}, \mathrm{ZnS},\left(\mathrm{SiO}_{2}\right)$ [39-43]), minerals [44] or ions (e.g., arsenic (III) [45]). The potential applications vary from sensing [45-47], separation, and processing [44] to templated nanoparticle synthesis, where phage display-selected peptides control the nucleation and growth of inorganic nanoparticles [48,49].

Bacteriophages are also utilized as delivery carriers [50]. Displaying specific peptides targeting eukaryotic cells or tissues compensates for the lack of natural mechanisms to enter mammalian cells or reach appropriate intracellular compartments. Non-modified phages are sometimes used, but the efficiency of virions containing cell-specific targeting peptides developed by phage display [51] or even phage-inspired nano-carriers [52] is superior. There is a possibility of coupling a variety of loads (e.g., drugs) by genetic manipulation $[53,54]$ or chemical conjugation $[55,56]$. Upon the recognition of the target, payloads might be released in a controlled manner. Hyman said that even despite the size of phages, they "only very loosely fit into the nanotechnology category" [57]. Therefore, here we focused on chemically modified systems and artificial designs.

Lambda phage was used as early as 1971 to deliver the gene for galactose transferase into human fibroblast cells isolated from a patient with a deficiency in this enzyme [58]. M13 was used for the targeted delivery of the GFP gene-expression cassette into breast cancer cells [59]. Filamentous phage f1 with targeting antibodies displayed on the tip of the virion was used as a carrier of chemically conjugated antibiotics [60]. Authors showed that such nanomedicine is non-toxic to mice, its immunogenicity is reduced in comparison to native phages, whereas the half-life of the conjugated phage increased in the bloodstream. Icosahedral MS2 phage might undergo genetic manipulation, chemical conjugation, and the removal of genetic material resulting in an empty nano-carrier, which might be loaded with the cargo of choice. For instance, Stephanopoulos et al. [61] showed the dual modified virus capsids: the cell-specific aptamer was conjugated to the unnatural amino acids ( $\mathrm{p}$-aminophenylalanine) displayed at the outer surface, whereas porphyrins were attached to the specially introduced cysteine residues at the inner surface. Upon the illumination of porphyrins, singlet oxygen was generated, which led to the selective destruction of target cells.

Recently, Zhu et al. [62] showed a prokaryotic-eukaryotic hybrid, composed of T4 phage and adeno-associated virus (AAV). The bacteriophage acted as the cargo, which might be reasonably easily modified. Th eukaryotic virus acted as a "driver" that allowed for cargo delivery into mammalian cells. The authors showed the example of the hybrid vector, where double stranded luciferase plasmid was packed into a T4 capsid, $\beta$-galactosidase was displayed at the phage capsid, and additionally, single stranded GFP DNA was packed in AAV capsid. This load was delivered simultaneously into the cell. The luciferase activity was four orders of magnitude larger compared to only T4 virions.

Phage proteins themselves can also assemble into nano-carriers for gene delivery [52]. For instance, the Petrenko group showed the encapsulation of siRNA by fused protein composed of phage capsid protein and targeting moiety [63]. The phage-mimetic nanoparticle was named "nanophage" as it comprises both protein shell and genetic material stored inside. "Nanophages" were used to deliver siRNA to the target region and cause gene silencing.

Phage-displayed peptides were also used to create artificial, nanoparticulate delivery systems. For instance, chitosan nanoparticles were conjugates with a phage-display selected sequence targeting the follicle-associated epithelium region of Peyer's patch [64]. This work is an example of a potential carrier for vaccine delivery. Other polymer-based nanoparticles, namely polyethylene 
glycol-poly(lactic-co-glycolic acid) (PEG-PLGA), modified with phage-displayed peptides, were used to target the brain [65]. The possibility to deliver drugs through the blood-brain barrier might impact the therapy of many central nervous system diseases. Interestingly, Ma et al. [66] showed the utilization of liposome modified with a specific phage-displayed peptide and loaded with DNA to target cell nuclei. The authors delivered the transposon system, which allowed the efficient insertion of transgenes into the host genome, into the nuclei of rat mesenchymal stem cells. Such a non-viral gene delivery vector is promising for stem cell therapy. Jin et al. [67] found a series of peptides prolonging the blood residence time for M13 bacteriophage. Later, they transferred this property to self-assembled heavy-chain ferritin nanocages. In addition, metal nanoparticles were decorated with specific, phage-displayed peptides. For instance, Wang et al. [68] developed Au@Ag heterogenous nanorods, which were directed by fusion proteins into cancer cells, where metallic nanostructures were used for photothermal ablation. In a similar example, Peng et al. [69] conjugated gold nanorods with chimeric phages that were engineered to specifically attach to several Gram-negative bacteria. Upon excitation by near-infrared light, gold nanorods release energy locally, generating heat that efficiently kills targeted cells.

In a different approach, bacteriophages were used as a molecular label [70]. The information was included in the DNA, which was later read using PCR-driven amplification. Bacteriophages were applied to label a nanoscaled bulk material, e.g., multi-walled carbon nanotubes.

\subsection{Phages as Antibacterial Agents: Phage Therapy, Biocontrol Applications}

The intrinsic efficiency of phages against bacteria resulted in the development of phage-derived antibacterials [71]. Bacteriophages have been used for medical purposes since the early 1900s [17,72]. Phages can support the development of inflammatory response against bacteria via the lysis of bacterial cell wall, which activates the immune system [73]. Therefore, phage therapies, i.e., the administration of phage cocktails to patients infected with bacteria, besides the direct elimination of bacteria cells, additionally activate the human immune system to fight against infection. Phage therapies were largely abandoned when antibiotics were developed [74]. However, the spread of drug-resistant superbugs and the lack of new medicines $[75,76]$ has caused a renaissance of bacteriophage-based antimicrobials [77]. Phages are therapeutically used to treat bacterial infections that do not respond to conventional antibiotics, particularly in Russia and Georgia [78]. In these countries, phage products are directly available, even without a prescription (e.g., "Intestiphage") [79]. The Russian company Microgen sells phages as liquid preparations or as pills [80]. In recent years, phage-based treatments reached clinical trials, e.g., curing inner ear infections [81], typhoid [82], or infected burn wounds ("Phagoburn" project) [83]. The "Phagoburn" project was terminated early because the utilized phage cocktails were proved to not be effective [83]. In 2019, the Food and Drug Administration approved the first clinical trial in the USA for intravenous phage therapy [84]. The very compelling reviews on the history of phage therapies are given by Abedon et al. [79] and Cisek et al. [16]. The summary of the current situation is given by Altamirano and Barr [85].

The ability of phages to kill target bacteria is also used in biocontrol applications, e.g., in the food industry and agriculture. The application of phages is safer compared to the utilization of antibiotics [86]. In 2017, the European Commission adopted the "EU One Health action plan against antimicrobial resistance". It was the first step toward the control of the use of antibiotics in agro-food production, as it is a major source of bacterial resistance acquisition [87]. Phages were used to protect dairy products [88], fruits [89], vegetables [90], meat [91], and fish [92]. Developments in the utilization of phages as antimicrobial agents in plant and animal agriculture at the farm level are summarized in a recent review by Svircev et al. [93].

\section{Bacteriophages in Materials Science}

The use of bacteriophages in sciences related to biology is an indigenous process. On the other hand, the application of phages in materials, composites, or even micro-robotics seems promising $[57,94,95]$. The nanometer virus structure is monodisperse and in the case of some phages, self-assembling [96,97]. 
Those features, followed by the rapid multiplication of uniform copies with a previously selected or even genetically engineered structure, are ideal for applying phages either as building components or templates/scaffolds for the production of novel bio/nanomaterials [98-102]. The physicochemical properties of individual phages determine the future use of phage-based nanomaterials. Phage resistance to temperature, solvent, or $\mathrm{pH}$ can considerably vary from one type to another $[103,104]$. In other examples, virions might be manipulated by the external stimuli, e.g., thanks to the permanent dipole moment $[105,106]$. Often, the usability of the given phage is directly related to the stability of the capsid, which may have been solvated or denatured under the operational conditions of the final material $[107,108]$. The overview of most prominent phage-related studies in the field of material science is shown in Figure 2.

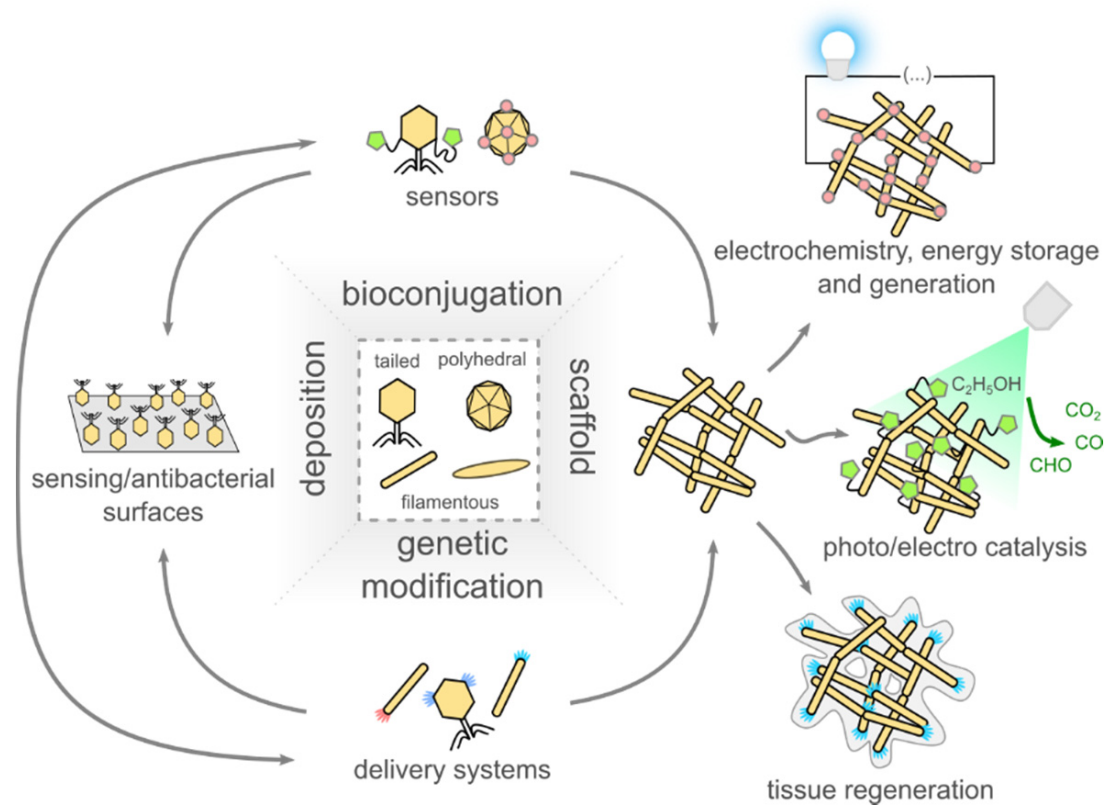

Figure 2. Scheme showing the main fields of application of bacteriophages in materials science. The main approaches are: (1) the utilization of the ability of phages to capture and infect bacteria, (2) taking advantage of the ease of virions modification, both by chemical and genetic means, and (3) using virions to produce scaffolds, later used, for example, in electrochemistry, energy storage, and generation application, for the production of catalysts and for tissue regeneration.

Bacteriophages are used in connection to 1D (nanoparticles), 2D (surface layers) and 3D (scaffolds) materials (Figure 3). In addition, three main approaches to synthesizing phage-based materials can be distinguished. First, the phage structure is unchanged, and usually, phages are still viable (e.g., the preparation of multifunctional conjugates composed of abiotic functional particles and phages [109], see Figure 3A). In such a case, the resultant materials often have applications in bio- or medicine-related applications [110]. The synthesis of such materials is usually done in water-based buffers and at a temperature close to room temperature. The second type of technological process exploits the nanometer dimensions of phages to create scaffolds or templates apart from their biological properties. For example, in an example of $\mathrm{TiO}_{2}$ porous material synthesis, phages are mixed with titanium isopropoxide/ethanol based solution $(50 \% \mathrm{v} / \mathrm{v})$ and calcinated at $500{ }^{\circ} \mathrm{C}$ [98]. The last type of phage-based materials uses selected phage building components as the empty capsid, structural proteins, receptors, or displayed peptides. Delivery systems or nanoparticles using specific, phage-displayed peptides were shown (cf. Section 2.1), but also, for example, Lee et al. [111] reviewed the possible applications of the bacteriophage Phi29 DNA packaging motor in nanotechnology and therapy. 
A
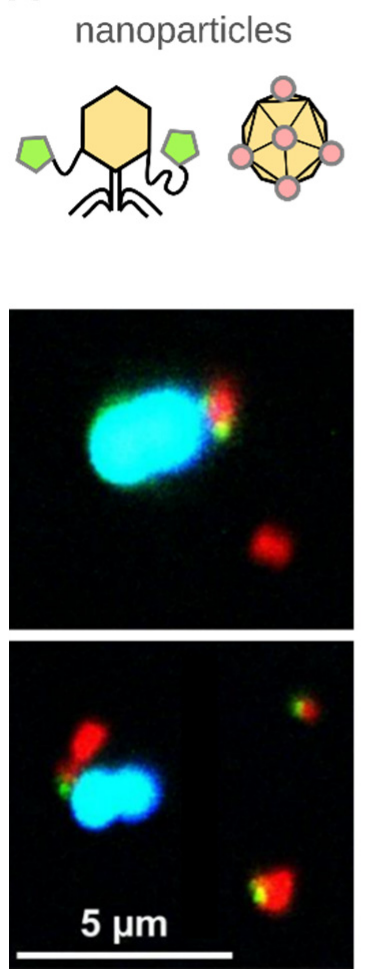

B
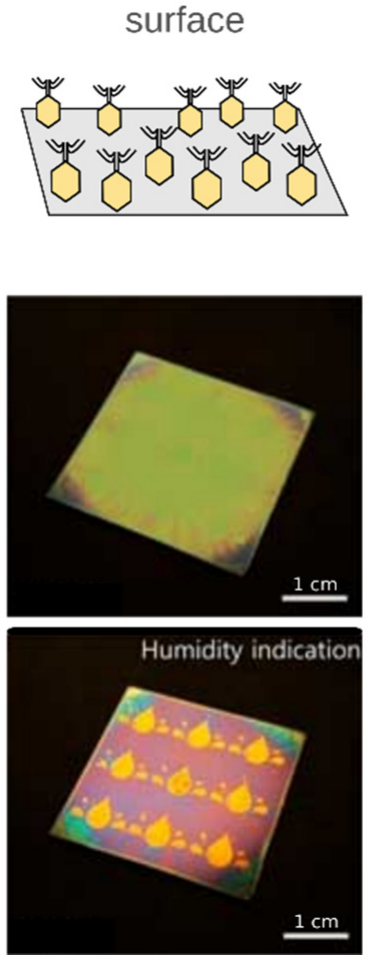

C
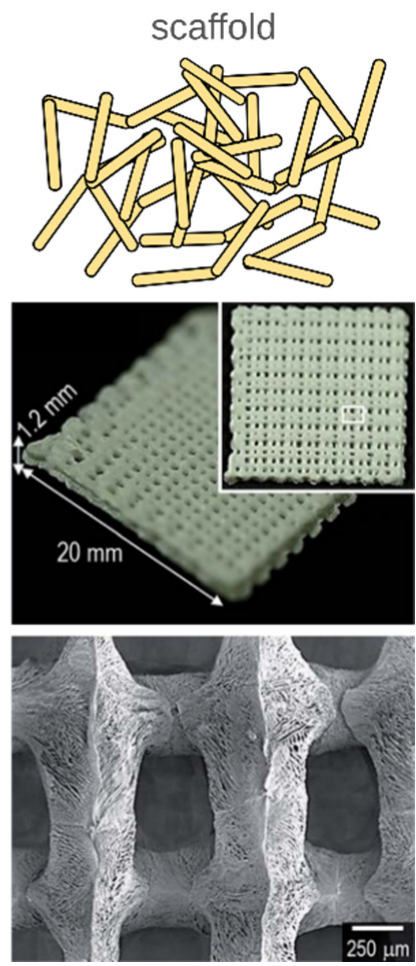

Figure 3. (A) Example of bioconjugates composed of multifunctional (magnetic and fluorescent) particles (red) and bacteriophages (stained green) used for the detection of bacteria (stained blue) using flow cytometry. Adapted with permission from reference [109]. Copyright 2017 American Chemical Society. (B) Phages deposited at the surface are often (but not exclusively) used for the preparation of antibacterial packaging or for sensing. Here, we demonstrate an example where the M13 phage layer rapidly responds to external factors (various volatile organic chemicals and endocrine-disrupting chemicals), displaying colorimetric behavior. Adapted from reference [112] based on the Creative Commons Attribution License (CC BY 4.0). (C) The monodispersity of virions and a variety of morphologies make phages great building blocks for scaffolds. Here, we show an example where a scaffold utilizing M13 phages and polymers (alginate and poly(E-caprolactone)) was suggested for use in bone tissue regeneration. Adapted from reference [113] with permission from the Royal Society of Chemistry.

\subsection{Antibacterial Materials}

Phages are used as antibacterial agents not only for phage therapies or phage control applications but also to prepare novel, nanostructured materials [114], i.e., wound dressings [115], packaging [116,117] or a membrane for water treatment [118], reducing the risk of bacterial infections. There are recent examples of combining phages with synthetic [119] and natural polymers (e.g., chitosan [120,121], alginates [91], collagen fibers [122]), even in the form of electrospun fibrous mats [123]. As phages are not harmful to humans, it is possible to create edible and antibacterial materials $[92,124,125]$. Leppänen and coworkers showed the immobilization of flavobacterium infecting bacteriophage at the surface of silicon and gold, both using bare surface and chemically modified surfaces [126]. Interestingly, the authors suggested how to measure the efficiency of such composites-they proposed to use "effective phage forming units (PFU)/surface area", as a comparable standard between different studies. Effective PFU is assessed by comparing the reduction in bacterial growth produced by the phage-modified materials to the effect caused by a known number of free phages. 
Phage virions were also used as stabilizing agents for the synthesis of gold nanoparticles, which have antibacterial and antibiofilm properties [127]. Hopf et al. [128] went further-they synthetized abiotic nanoparticles, with a structure was similar to viruses, and named them phage-mimicking antibacterial core-shell nanoparticles. However, in this case, the antibacterial properties were mainly derived from silver coating, which was deposited in an anisotropic fashion on the gold nanospheres, which earlier were conjugated to relatively large silica particles.

Tolba et al. [129] used recombinant bacteriophages (bearing biotin carboxyl carrier protein gene or the cellulose-binding module gene) for the oriented immobilization of bacteriophage T4 at streptavidin-coated magnetic beads and cellulose-based materials. Later, Richter and coworkers $[105,106]$ showed the ordered deposition of a T4 phage onto a gold surface (and a chemically modified gold surface). The authors utilized a large dipole moment of virions to orient them in the external electric field. Such an approach allowed more receptor binding proteins to be exposed and available for interactions with the bacteria. In the case of random deposition, steric hindrances decreased the activity of phage layers.

There might be additional benefits derived from the utilization of phage-modified materials. Meyer et al. [130] showed the stabilization of T4 virions deposited onto papers in comparison to free phages against extreme $\mathrm{pH}$. Leung et al. showed the preservation of the antimicrobial activity of P100, CG4, and AG10 bacteriophages in sugar (pullulan-trehalose mixture) as dried films and as coatings on food packaging [131,132]. In addition, Kimmelshue showed the prolonged storage time of CN8 phages when polyvinyl alcohol was used [119]. Fixed Phage Ltd. (Glasgow, UK) is developing both spray-based methods as well as films and biomaterials, having antibacterial properties for use in agriculture, food, veterinary, and personal health.

\subsection{Biosensors}

The natural ability of phages to capture host bacteria was used to develop phage-based methods for bacteria detection. Only the recognition of a proper and viable host assures the multiplication of virions and the completion of the life cycle of bacteriophages. This gives the advantage over other broadly used methods, e.g., PCR or mass spectroscopy-based, which are prone to false positives in case of the presence of dead bacteria. Compared to antibodies, phages are much cheaper and easier to prepare, whereas standard biochemical or culturing methods require a much longer time to generate an outcome $[133,134]$.

There are two main designs of phage-based biosensors [133-137]. Methods, where the analytical signal is generated upon bacteria capturing (at the surface of the sensing elements or by phage-based probes), are fast, but a single event is difficult to detect, and thus the limits of detection (LOD) are relatively high. In contrast, infecting bacteria and utilizing their molecular machinery to amplify the signal (progeny virions, products of reporter genes, or metabolites) offers low detection limits, but the procedures are time consuming. There is still a need to develop methods allowing for the LOD in a range below 10 colony forming units (CFU)/mL achieved in under one hour and in complex samples [133]. In the case of sepsis in neonates, the limiting concentration of bacteria in the blood is $10 \mathrm{CFU} / \mathrm{mL}$ [138]. However, medical doctors are willing to wait only one hour before the administration of wide-spectrum antibiotics [139]. Another challenge is to lower the limit of detection to around $1 \mathrm{CFU} / 100 \mathrm{~mL}$, which is needed for the analysis of drinking water [140].

The best balance between LOD and the time of analysis was reported in 2020 by Farooq and coworkers, who were able to detect $3 \mathrm{CFU} / \mathrm{mL}$ within $30 \mathrm{~min}$. The authors used high-density layers of phages immobilized onto cellulose for the detection of Staphylococcus aureus, employing differential pulse voltammetry [141]. A similar solution was shown by Xu et al. [142], who achieved $14 \pm 5 \mathrm{CFU} / \mathrm{mL}$ of Escherichia coli within $20 \mathrm{~min}$, also using differential pulse voltammetry. Sedki et al. [143] achieved $14 \mathrm{CFU} / \mathrm{mL}$ of E. coli after $30 \mathrm{~min}$ of incubation using virions chemisorbed on a glassy carbon electrode decorated with gold nanoparticles and employing electrochemical impedance spectroscopy. Carboxyl graphene-PaP1 phages composite drop-casted onto the glassy carbon electrode allowed for the 
detection of Pseudomonas aeruginosa with an LOD of $56 \mathrm{CFU} / \mathrm{mL}$ and within $30 \mathrm{~min}$. The read-out was achieved using electrochemiluminescence [144]. All of the aforementioned cases capturing a bacterial cell by surface-bound virions resulted in local changes of electric properties, which were later detected through electrochemical methods. Such an approach not only favors but requires fast detection as after a few to a few tens of minutes, the captured bacteria are usually destroyed, and progeny virions are released. This issue might be overcome by using only parts of virions, e.g., receptor binding proteins (RBPs) [145,146].

The utilization of the molecular machinery of the host allows for the detection of (a) progeny virions, (b) bacterial metabolites, and (c) reporter molecules, which were encoded in the modified genetic material of the phage probe. In all these cases, the bacterial cell acts as a signal amplifier, allowing for low LOD, but in exchange for a prolonged time of analysis. The first phage-based method reaching the limit of detection of $1 \mathrm{CFU}$ per $100 \mathrm{~mL}$ utilized such an approach and was reported in 2003. Neufeld et al. [147] used virulent phage typing combined with the amperometric detection of cell marker enzyme activity $\beta$-D-galactosidase, release upon cell disruption, to achieve 1 CFU per $100 \mathrm{~mL}$ detection from 6 to $8 \mathrm{~h}$. In 2018, the Nugen group reported a different phage-based approach, which also allowed for an LOD of 1 CFU per $100 \mathrm{~mL}$ achieved within around $10 \mathrm{~h}$. The authors developed a filtration-based method utilizing genetically modified T7 phages. The genes for the reporter enzymes, i.e., a luciferase and an alkaline phosphatase, were fused to genes for carbohydrate-binding modules specific to cellulose. Reporter phages were used to infect E. coli trapped on a cellulose filter. The binding moieties facilitated the immobilization of the reporter probes released from the target cells upon their lysis [148]. The Nugen group also showed a syringe-based sensor utilizing the same T7 genetically modified phages with luciferase fused with carbohydrate-binding modules to achieve 20 CFU per $100 \mathrm{~mL}$, but the time of analysis was reduced down to $5 \mathrm{~h}$, which is two times shorter compared to the filtering-based method [140].

Progeny virions are usually detected by means of qPCR. Recently, Anany et al. [149] showed an interesting example, where phages were printed onto paper strips using modified inkjet. A phage dipstick was used to capture and infect E. coli O157:H7, E. coli O45:H2, and Salmonella Newport in spinach, ground beef, and chicken homogenates, respectively, and the reported LOD was in the range from $10 \mathrm{CFU} / \mathrm{mL}$ to $50 \mathrm{CFU} / \mathrm{mL}$ in $8 \mathrm{~h}$.

Time and LOD might also be balanced by introducing the pre-enrichment step. For instance, in the case of work by Laube and coworkers [150], the phagomagnetic separation of bacteria labeled with antibodies conjugated with horseradish peroxide allowed for an LOD of $19 \mathrm{CFU} / \mathrm{mL}$ in $2.5 \mathrm{~h}$. When samples were pre-enriched for $6 \mathrm{~h}$, the LOD decreased to around 1.4 CFU per $25 \mathrm{~mL}$.

Bacteriophages were also used for the detection of other analytes, e.g., ions [45] or organic compounds (an example of the device is shown in Figure 3B) [112]. Not only phage-displayed peptides [45] but also whole virions were used. For instance, Armon and Kott reviewed the use of bacteriophages as indicators of pollution [151]. Based on the bacteriophage persistence in water and their related survival time to human viruses, it was proposed to use bacteriophages as a useful index of viral pollution. It was shown that coliphages might be used as indicators of airborne viruses and enteric viruses. Some phages are also indicators of recreational water quality or even fecal indicators. Very recently, Kim et al. [152] showed the utilization of bacteriophage-based colorimetric sensors for the detection of medical chemicals. Three variants of the M13 phage were used: $w t$, and two others that displayed specific peptides which changed the hydrophobic/hydrophilic balance of virions, respectively. Red, green, and blue colored pixels of the array were achieved by varying pulling speeds upon the preparation of phage films. A color pattern was formed as a unique response value to a given analyte. A similar colorimetric method was used to detect the volatile organic chemicals and endocrine-disrupting chemicals [112]. 


\subsection{Phage-Based Scaffolds}

The structure of phages allows the creation of templates or scaffoldings, which can be further used in multiple applications. The most promising and thus exploited are filamentous phages, i.e., Ff, $\mathrm{f1}$, Ike, fd, Pf1, and M13. Their length (up to $800 \mathrm{~nm}$ ) and width (down to $8 \mathrm{~nm}$ ) are perfect for the synthesis of nanowires and the fibrous components of composites [99,153-157].

Recently, more attention has been paid to the use of bacteriophages as components of materials designed for tissue regeneration. To restore the integrity of irreversible tissue damage, caused by diseases or accidents, a transplant from either the host itself or other donors (including humans or animals) is performed. In order to reduce the waiting time for transplants, artificial materials are being designed. Such materials mimic a natural supporting matrix-the extracellular matrix (ECM) — on which new cells can properly migrate, differentiate, and proliferate $[143,148]$. The strategies showed that the size and different design of scaffold could positively affect vascularization in newly formed tissue. The most promising experiments combined selected scaffold, the application of tissue-specific therapeutic cells (i.e., stem cells), and bioactive molecules (e.g., cytokines and growth factors). The chosen sequences of polypeptides are used as a growth stimulant [158]. However, the cost of such therapy may be a massive obstacle. The new strategies exploit genetically engineered phages as an inseparable component of an artificial ECM (see Figure 3C) to suppress the diffusion of polypeptides $[113,159]$. The genome of a phage is modified to expose multiple desired sequences of polypeptides at the surface of the capsid. Researchers show that the presence of phages in the human body is bioneutral, which is encouraging for their application. The application of phage display substrates in scaffolds was already shown in many materials designed for the regeneration of different tissues (i.e., cartilage, bone, or neural) [113,160-166].

Phages can be used for designing surface-enhanced Raman scattering (SERS) sensors by implementing phage display with the noble metal-binding motif. SERS sensors are usually based on nanostructured silver or gold surfaces [167-169]. The nanoarchitecture of those metals enhances the electromagnetic field of excitation light, which amplifies the signal from the analyte. The efficiency of enhancement of a given SERS substrate depends on the number of those nanostructures and their arrangement in the material. The M13 phage with a genetically modified protein coating was used to develop a scaffold for silver-based sensors [170]. The arrangement of a filamentous phage coated with metal particles enables the production of fiber-like material where hot spots are located either at the end or at contact spots of nanowires. The structure of the sensor showed an interesting pattern which could be useful in other applications. However, SERS substrates demand a denser hot spots layer in commercial materials (i.e., SERSitive; Warsaw, Poland).

\subsection{Bacteriophages in Electrochemistry, Energy Storage and Generation}

Bacteriophages have become useful in the production of materials used for electronics, such as small and flexible batteries or energy-harvesting devices $[99,100,155,156]$. Interest in phage-based batteries increased after 2006 when the Belcher group used M13 as a template for nanowires made of cobalt oxide $\left(\mathrm{Co}_{3} \mathrm{O}_{4}\right)$ [171]. Such a design of electrodes became widely popular among scientists in the next years of research, where cobalt oxide was replaced by a variety of materials (i.e., single-wall carbon nanotubes [99,102], silver nanoparticles [172], nickel or even sulfur [99,173]).

The M13-based template was also used to synthesize a nanostructured $\mathrm{FePO}_{4}$ cathode for sodium-based batteries [174]. The cathode scaffold was obtained by modifying the phage capsid with a single-wall carbon nanotube (SWCNT) binding peptide motif. The cathode, resembling a corn cob and composed of M13, SWCNT, and Fe nanoparticles, was used to produce the $\mathrm{Na} / \mathrm{Bio}-\mathrm{FePO}_{4}-\mathrm{CNT}$ battery with a discharge capacity equal to $166 \mathrm{mAh} / \mathrm{g}$ at a $\mathrm{C} / 10$ rate $(1 \mathrm{C}=150 \mathrm{~mA} / \mathrm{g})$.

A similar strategy to augment the contact area can be used to produce anodes using a nanofoam M13 phage-based scaffold [101]. In the initial step, M13 phages with EEAE (glutamic acid, glutamic acid, alanine, glutamic acid) metal (i.e., Ni) binding motif were crosslinked using glutaraldehyde. The phage scaffold was then metalized in the deposition bath using hypophosphite as a reducing agent. 
The amount of $\mathrm{NaH}_{2} \mathrm{PO}_{4}$ used during this step allowed for control over different Ni-P alloy phase compositions (i.e., $\mathrm{Ni}_{3} \mathrm{P}, \mathrm{Ni}_{2} \mathrm{P}$, and $\mathrm{Ni}_{5} \mathrm{P}_{4}$ ). The final product was used in lithium battery, which showed that a virus-based template enables obtaining $677 \mathrm{mAh} / \mathrm{g}$ discharge capacity, which was reduced by $20 \%$ after 100 cycles.

The piezoelectric properties of phages (i.e., M13) results from uneven distribution of charges within the phage capsid structure. The uneven distribution of charges is even observed within single coat protein pVIII (positively charged amino acid residues at the end of $\mathrm{C}$ terminus and the negative ones near $\mathrm{N}$ terminus). Under mechanical stress, the phage capsid structure is deformed, which changes the distance between charges. The change in directional polarization generates an electric field. The properly prepared device can register and collect this energy in the form of current flow. This opens the possibility of assembling the layers of ordered bacteriophages or other nanostructures towards the production of flexible piezoelectric energy generators $[100,175]$. Currently, the electric outcome generated within such energy harvesters is still below commercial expectations. The highest efficiency was obtained by Lee's group, which used devices based on the vertically aligned M13 phage with genetically engineered coat proteins ( $\mathrm{pVIII}$ with YEEE (tyrosine, glutamic acid, glutamic acid, glutamic acid) and pIII with $6 \mathrm{H}$ (6 histidines) motif). The design was based on phages self-assembling on Ni-NTA (nitrilotriacetic acid)/Au electrode using a polydimethylsiloxane (PDMS) mold. After the phage deposition, the surface was exposed to UV-light to crosslink the peptide residues between the phages. This approach stabilized the geometry of phages and their electrical and mechanical properties, which enhanced the piezoelectric effect. Finally, the energy harvester was formed by covering the phage layer by the second gold electrode. A combination of five such devices was enough to turn on the backlight of the LCD panel just by force from the pressing of the finger [99].

Perovskites are still gaining interest in the material science community. An innovative solution for increasing the packing of perovskite grains was presented in a work published by Hao-Sheng et al. [176]. The aim of the study was to create a solar cell in which the perovskite layer used the connection between the building grains with the help of M13 phages. The obtained material allowed for the increase in the efficiency of the solar cell from $17.8 \%$ to $20.1 \%$. It is noteworthy that the connection with the lead perovskite took place without the need for the genetic modification of the phage. This shows that the phages do not have to act as a scaffold but can act as an adhesive element, which is possible to be heated to $90^{\circ} \mathrm{C}$ without breaking the material. Following a similar approach, optoelectronic organic solar cells and the organic light-emitting diode was proposed by Lee et al. [177]. The authors exploited the ability of genetically modified bacteriophages to bind Ag/Au nanoparticles. The created scaffold consists of various noble metallic particles, which allowed for prominent localized surface plasmon resonance. The layer of the created biocomposite was directly applied as an element of solar cells and the diode. The material showed better photophysical properties in both devices; power conversion efficiency increased by $15.5 \%$ (for solar cell); threefold higher luminescence than the pristine devices $\left(\approx 29,000 \mathrm{~cd} \mathrm{~m}^{-2}\right.$ vs. $\left.9000 \mathrm{~cd} \mathrm{~m}^{-2}\right)$ was observed, and external quantum efficiency was increased by $22.6 \%$ (for the organic diode).

\subsection{Bacteriophages in Catalysis}

Irreversible transformation in the current century will change the standard methods of obtaining energy (i.e., burning fossil fuels), in favor of alternative energy sources. One of them is fuel cells-based on the electrochemical transformation of non-fossil fuels (i.e., ethanol, methanol, glucose, hydrogen) into electricity. The catalytic process often utilizes gold or platinum nanoparticles. To overcome power limitations (and increase efficiency), scientists increase the accessibility of active sites by remodeling the two-dimensional morphology of fuel cells into three dimensions. The metal-binding residues on the phage capsid were recently used to develop high-surface-area catalysts for fuel cells. Belcher exploited filamentous M13 scaffolds to prepare gold nanowires for carbon oxide electro-oxidation [178]. The obtained stability and high yield of the created cell allowed further improvement by covering the gold nanowire with platinum atoms. Such developed Au-Pt core-shell nanowires enabled carrying 
out the ethanol oxidation process, which significantly improved the perspectives of the application of such design. Authors designed cells with different atomic ratios of gold to platinum (2.6:1, 1.8:1, 1:1), which appeared to generate an up to 6.5 times higher steady-state current compared to a cell composed of only platinum $\left(0.13 \mathrm{~mA} / \mathrm{cm}^{2}\right.$.) Four years later, Dunn's group further developed the phage-based ethanol oxidation idea by binding gold nanoparticles covered with enzyme-glucose oxidase to phage-based scaffolds [179]. The combination of AuNP and enzyme molecules allowed the direct electron transfer in the designed biofuel cell. The achieved peak current of $1.2 \mathrm{~mA} / \mathrm{cm}^{2}$ was higher compared to other works using similar effects.

Hernández-Gordillo et al. [98] presented the application of M13 phages to create porous $\mathrm{TiO}_{2}$ material. Titanium alkoxide and ethanol were mixed with phage suspensions. The mixture was calcinated at $500{ }^{\circ} \mathrm{C}$. The final material had pores with an average size of $8.2 \mathrm{~nm}$. Although the authors did not perform any photocatalytic studies, such templates based on either $\mathrm{TiO}_{2}$ or $\mathrm{ZnO}$ should be beneficial in terms of photocatalytic activity. The efficiency of photoelectrodes benefits from increasing the surface area by imposing porosity. M13 phage scaffolds have been introduced as an improvement of the technological process for the production of $\mathrm{TiO}_{2}$ photoelectrodes. The application of pure $\mathrm{TiO}_{2}$ is limited by the energy bandgap ( $3.2 \mathrm{eV}$ and $3.02 \mathrm{eV}$ for anatase and rutile structure, respectively). Efficient photoelectrodes are usually obtained by doping or combining $\mathrm{TiO}_{2}$ with other materials. Promising phage-templated photoelectrodes were prepared as hybrids with carbon nanotubes or noble metal (i.e., $\mathrm{Au}$ or $\mathrm{Ag}$ ) nanostructures, showing the absorbance beyond $400 \mathrm{~nm}$ with a resonance band in visible spectra (ca. $550 \mathrm{~nm}$ ) [156,180,181].

\section{Bacteriophages in Soft Matter and Physical Chemistry}

Bacteriophages play a valuable role in soft matter research. Phages are well defined soft materials of a variety of sizes and structures that form colloidal suspensions. The suspension of a small concentration of the selected phage (e.g., rod-like) dispersed in the solvent possesses isotropic properties, i.e., all virions are randomly oriented. However, upon an increase in concentration, phages can assemble into oriented anisotropic phases (i.e., liquid crystalline phases, see Figure 4). In the case of phage colloids, the system maximizes the entropy by lowering the number of states in which "phage-molecules" can subsist and increase the number of available states to the solvent molecules. Such behavior is observed and well defined as phase transitions in liquid crystals [157,182,183]. The possibility of the genetic modifications of the capsid proteins or changing the size of virions makes the phages an efficient toy model for analyzing or programming the self-assembly process. The highly concentrated colloids of filamentous or rod structure phages can produce not only one-dimensional orientation but also more complex phases as smectic, chiral, or even colloidal membranes [182]. Interesting patterns are observed when two types of different sized phages are mixed or when phages are mixed excluding the space polymers of high molecular weight. Understanding the interactions between virions and also between the main building components of phage-proteins, is necessary to produce even more complex and ordered structures. Sawada reviewed the virus-based soft materials obtained via controlled assembly through liquid crystalline formation [96]. Not only whole virions but artificial assemblies are also useful. Spakova et al. [184] extracted a phage tail tube building protein (gp39) from the phage NBD2 and recombined it in E. coli bacteria and yeast, Saccharomyces cerevisiae. After the incubation of bacteria, the protein was extracted and purified by the SDS-PAGE method. The phage protein tubes derived from both bacteria had a diameter of $12 \mathrm{~nm}$ and a length varying from $0.1 \mu \mathrm{m}$ to more than $3.95 \mu \mathrm{m}$. The poly-protein tube was, on average, 23 times longer than the natural length of the phage $(170 \mathrm{~nm})$, which was caused by the absence of other capsid proteins that could regulate the building process. 
A polymer solution

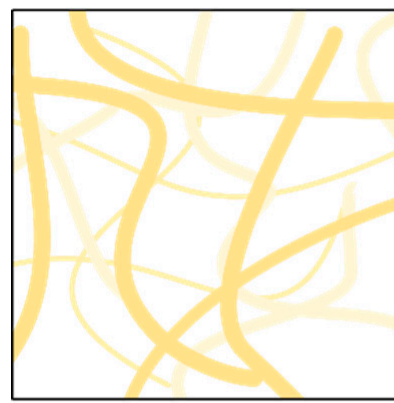

B

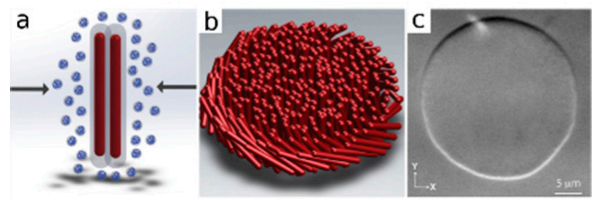

phage solution low concentration

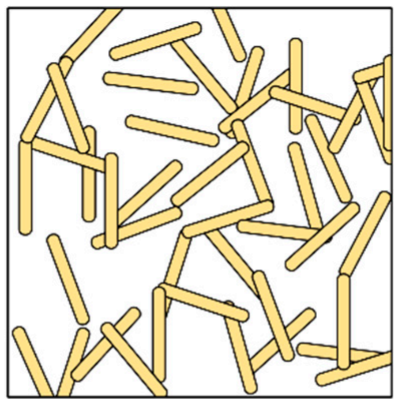

C

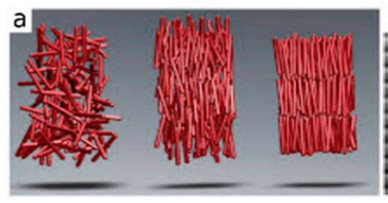

phage solution high concentration
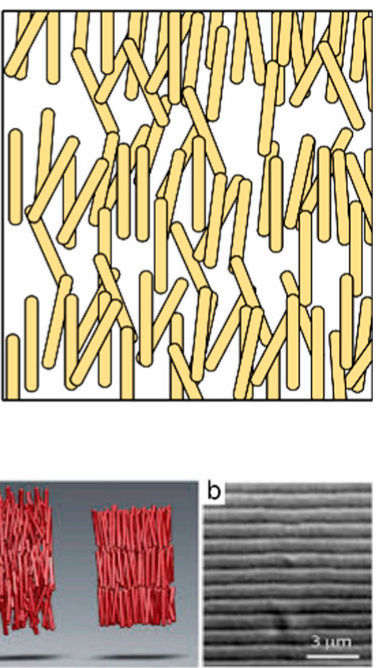

Figure 4. (A) Polymers usually form random coils at low concentrations, which interdigitate, creating meshes above the overlap concentration. However, phages, especially filamentous, are stiff colloidal rods. This property was used to study a number of physicochemical phenomena, e.g., transport and sedimentation, in an unusual crowded environment. In high concentrations, filamentous phage forms liquid crystalline phases. (B) (a) Non-adsorbing polymer causes attractive interactions between rod-like particles due to depletion. (b) The schematic representation of a 2D colloidal membrane composed of rod-like particles. (c) Differential interference contrast microscopy image showing a colloidal membrane formed by an fd phage. (C) (a) Cartoon showing the arrangement of rods in an isotropic, nematic, and smectic liquid phase. (b) Differential interference contrast microscopy image showing one-rod-length-long smectic layers. (B) and (C) are adapted from reference [157] based on the Creative Commons Attribution License (CC BY 4.0).

The highly concentrated solutions of phages have also contributed to the research of the diffusion in complex liquids. The Brownian diffusion of molecules is a ubiquitous process in nature. The conventional diffusion equation defined by Einstein and Smoluchowski allows for the prediction of the mean distance and time of travel of a particle at given environmental conditions $[185,186]$. These models are the basis for the description of the reaction kinetics in diffusion-limited reactions. However, in the complex liquids, the diffusive motion of macromolecules fails to be described by standard models. The anomalous diffusion is attributed to macromolecular crowding along with the accompanying interactions (attraction and depletion) [187]. For example, the cell interior consists of a filamentous network that permeates the cell volume filled with differently sized proteins, lipids, and sugars. Multiple toy models of differently sized objects are used to resemble crowded environments at various configurations [188]. The application of phages as a crowding agent allowed for description of the diffusion in selected subsystems, where crowders possessed a monodispersed, rigid structure with chosen phase orientation (e.g., isotropic, nematic). To obtain new insights into the theory of diffusion, mostly filamentous phages are used in both experimental and computer simulation approach [189-191]. The experiments show that the isotropic suspensions of different concentrations of fd phage $(7 \mathrm{~nm} \times 890 \mathrm{~nm})$ can highly affect the diffusion of proteins (apoferritin, hydrodynamic radius: $3.5 \mathrm{~nm}$ ) [192,193]. The change of the diffusion coefficient is even more evident in the nematic phase, where it can be analyzed along or perpendicular to the orientation vector of virions.

When particle sizes become larger, diffusion under the influence of Brownian motion begins to be overpowered by the sedimentation process. The stability of monodisperse suspension is essential from the perspective of industrial applications, e.g., to extend the shelf life of food products. The influence of particle concentration, size, and external stress on the particle's motion can provide valuable insights 
into the sedimentation process. This phenomenon was investigated by using non-interacting colloidal rods-fd and pf1 bacteriophages. In the work of Barabé et al. [194], the authors determined the correlation of reducing sedimentation as a function of the concentration of bacteriophages. By the application of two times longer rods, they observed the sedimentation speed decrease of two orders of magnitude compared to the same concentrations of shorter rods.

The highly concentrated suspension of fd phages $(95 \mathrm{mg} / \mathrm{mL})$ can organize into lamellar form. The formed stripwise pattern is repetitive, even at the macroscale. Alvarez et al. showed how the modified fd phage of different sizes (1.3 times bigger than used as crowder) diffuses in such a heavily complex system [154]. In this semi-crystalline system, diffusion is locally reduced from 3D to 1D, which is statistically the slowest type of diffusion (in terms of traveled distance). By the comparison of mean square displacement (MSD) determined from the trajectories of the labeled host and modified guest viruses, the authors showed that the guests' diffusion was up to two times faster and much more prone to hopping-type diffusion (to the second column of phages/stripe).

Research on the formation of phage-based liquid crystal structures is not only a conceptual study, but examples of such constructs/formations are found directly in nature. P. aeruginosa is a bacterium that causes respiratory disease in humans—cystic fibrosis. The bacteria are infected by the Pf bacteriophage of rod-shaped structure [195]. Although bacteriophages are natural enemies of bacteria, the Pf phage contributes to a symbiotic-like relationship with bacteria [196,197]. During airway infections, bacteria tend to form a biofilm in which they multiply in the formed polymer matrix together with the phage. The rod-shape structured phage in high concentrations can order some of the space in the biofilm matrix into a crystalline structure. The research shows that bacteria that exhibit ordered biofilm possess higher resistance to antibiotics (i.e., tobramycin). This effect was explained by the formation of a denser polymer matrix capable of trapping antibiotic molecules. This not obvious symbiotic relation between phage and bacterium is responsible for morbidity increase and complicates the patient's treatment.

Furthermore, the possibility of the genetic engineering or/and chemical modification of the capsid can significantly influence the physicochemical properties of the formed phases. Grafting polymers of different properties (e.g., thermoresponsive poly(N-isopropylacrylamide, PNIPAM) on a phage's capsid affect the formation of standard liquid crystal phases and increase their stability [198,199]. The observations in the self-assembly process have already found beneficial applications in material sciences.

\section{Concluding Remarks}

This review shows that phages are gaining importance in various aspects of nanoscience. One could think that phages are useful only in applications when bacteria detection/identification is needed. In fact, phage therapies, biocontrol agents, sensors for bacteria detection, and antibacterial materials constitute important fields of study providing solutions for vital problems of the current world. However, phages proved to be useful and monodispersed building blocks and templates in nanotechnology, physical chemistry, and material science, due to their abundance corresponding to the variety of morphologies, robustness, ease of preparation, and ease of modification. The Nobel awarded phage-display technique caused an explosion of new and exciting examples of phage utilization.

The connection between nanotechnology and bacteriophages should be reciprocal: nanotechnology might and should allow for the modulation of the stability of bacteriophages. Even despite some phages are "tough", some other species might lose activity under various physicochemical and physiological conditions. Phages are usually not selected based on their resistance to external factors, but rather due to their virulence, selectivity, ease of manipulation or modification. The recent review by Jończyk-Matysiak et al. [200] described factors determining phage stability, with emphasis on the effect of chemical substances, $\mathrm{pH}$, freezing, heat, UV-light, and methods of preparation and formulation. This appears crucial, as for instance, in the case of the "Phagoburn" project, the patients received a very low dosage of phages $\left(10^{2} \mathrm{pfu} / \mathrm{mL}\right.$ daily). The titer of administered phages decreased by a 
thousand-fold within 15 days after production. A lack of stability was an essential factor causing the failure of the trial [83].

Different preservation methods, i.e., storage at $4{ }^{\circ} \mathrm{C}$, freezing and storage at $-80{ }^{\circ} \mathrm{C}$ or in liquid nitrogen, or the storage of dried or lyophilized phages, are used. Golec et al. proposed the method to store tailed phages [201] inside the infected cells at $-80{ }^{\circ} \mathrm{C}$ without a major loss of phage and host viability. Immobilization [130] or encapsulation [202] was also showed to be efficient in increasing phage stability. Gonzalez-Menendez showed a comparative analysis of different preservation techniques for the storage of Staphylococcus phages [203].

Phage-based products might also take advantage of studies on the stabilization of eukaryotic viruses. The World Health Organization recognized the issue of protecting vaccines as one of the most critical challenges [204]. Nevertheless, only empirical solutions are available. For instance, the utilization of sucrose at molar concentrations for vaccine formulations has been in development [205-207]. Stewart et al. [208] demonstrated the preservation of adenovirus in the case of sucrose-stabilized liquid formulation for up to 6 weeks at $40{ }^{\circ} \mathrm{C}$. Recently, a paper in Nature Communication coming from the Stellacci and Vitelli groups [209] described gold nanoparticles that improved the storage time of adenovirus type 5 at concentrations of several orders of magnitude lower compared to sucrose. Nano-based solutions for the stabilization of phages are yet to come.

On the other hand, phages are also enemies when they cause the contamination of bacteria-based biotechnological processes. Phage outbreaks may contribute to significant economic losses due to delays in processing and manufacturing, the poor quality of the product, material contamination, and eventually complete production loss [210]. Physical or chemical agents are used, but more versatile, safe, and user-friendly methods of the deactivation of bacteriophages are needed [200]. Nanotechnology gives a promise to provide a solution. Very recently, Richter et al. [211] found anti-phage nanoparticles that could be added directly into the bioreactors. The studied gold nanoparticles were effective against the T1, T4, and T7 phages. The reported decrease in titers was in the range from 2 logs within $5 \mathrm{~h}$ at $50{ }^{\circ} \mathrm{C}$ up to 5 logs after $24 \mathrm{~h}$ exposure. The combination of negatively charged and hydrophobic capping ligands was key for effective phage deactivation (inhibitory concentration of $\mathrm{EC}_{50} \leq 1 \mu \mathrm{g} \mathrm{mL}{ }^{-1}$ ).

Author Contributions: Conceptualization, J.P.; writing—original draft preparation, J.P. and K.B.; writing—review and editing, J.P. and K.B.; visualization, K.B.; supervision, J.P.; funding acquisition, J.P. All authors have read and agreed to the published version of the manuscript.

Funding: The research was financed by the National Science Centre, Poland, within SONATA BIS grant number 2017/26/E/ST4/00041.

Conflicts of Interest: The authors declare no conflict of interest.

\section{References}

1. Delgado-Ramos, G.C. Nano-Conceptions: A Sociological Insight of Nanotechnology Conceptions. J. Philos. Sci. Law 2006, 6, 25-57. [CrossRef]

2. Kan, M. Intel: Sorry, But Our $7 \mathrm{~nm}$ Chips Will Be Delayed to 2022, 2023. Available online: https://www.pcmag.com/news/intel-sorry-but-our-7nm-chips-will-be-delayed-to-2022-2023?utm source=email\&utm_campaign=whatsnewnow\&utm_medium=title (accessed on 23 July 2020).

3. Grzybowski, B.A.; Huck, W.T.S.S. The nanotechnology of life-inspired systems. Nat. Nanotechnol. 2016, 11, 585-592. [CrossRef] [PubMed]

4. Grzybowski, B.A.; Fitzner, K.; Paczesny, J.; Granick, S. From dynamic self-assembly to networked chemical systems. Chem. Soc. Rev. 2017, 46, 5647-5678. [CrossRef]

5. Sharma, S.; Chatterjee, S.; Datta, S.; Prasad, R.; Dubey, D.; Prasad, R.K.; Vairale, M.G. Bacteriophages and its applications: An overview. Folia Microbiol. (Praha) 2017, 62, 17-55. [CrossRef]

6. Ackermann, H.-W. 5500 Phages examined in the electron microscope. Arch. Virol. 2007, 152, $227-243$. [CrossRef] [PubMed]

7. Dion, M.B.; Oechslin, F.; Moineau, S. Phage diversity, genomics and phylogeny. Nat. Rev. Microbiol. 2020, 18, 125-138. [CrossRef] 
8. Jain, R.; Srivastava, R. Metabolic investigation of host/pathogen interaction using MS2-infected Escherichia coli. BMC Syst. Biol. 2009, 3, 121. [CrossRef]

9. de Jonge, P.A.; Nobrega, F.L.; Brouns, S.J.J.; Dutilh, B.E. Molecular and Evolutionary Determinants of Bacteriophage Host Range. Trends Microbiol. 2019, 27, 51-63. [CrossRef]

10. Trasanidou, D.; Gerós, A.S.; Mohanraju, P.; Nieuwenweg, A.C.; Nobrega, F.L.; Staals, R.H.J. Keeping crispr in check: Diverse mechanisms of phage-encoded anti-crisprs. FEMS Microbiol. Lett. 2019, 366, 1-14. [CrossRef]

11. Faure, G.; Shmakov, S.A.; Yan, W.X.; Cheng, D.R.; Scott, D.A.; Peters, J.E.; Makarova, K.S.; Koonin, E.V. CRISPR-Cas in mobile genetic elements: Counter-defence and beyond. Nat. Rev. Microbiol. 2019, 17, 513-525. [CrossRef]

12. Brigati, J.R.; Petrenko, V.A. Thermostability of landscape phage probes. Anal. Bioanal. Chem. 2005, 382, $1346-1350$. [CrossRef]

13. Nobrega, F.L.; Costa, A.R.; Santos, J.F.; Siliakus, M.F.; Van Lent, J.W.M.; Kengen, S.W.M.; Azeredo, J.; Kluskens, L.D. Genetically manipulated phages with improved $\mathrm{pH}$ resistance for oral administration in veterinary medicine. Sci. Rep. 2016, 6, 1-12. [CrossRef] [PubMed]

14. Olofsson, L.; Ankarloo, J.; Nicholls, I.A. Phage viability in organic media: Insights into phage stability. J. Mol. Recognit. 1998, 11, 91-93. [CrossRef]

15. Olofsson, L.; Ankarloo, J.; Andersson, P.O.; Nicholls, I.A. Filamentous bacteriophage stability in non-aqueous media. Chem. Biol. 2001, 8, 661-671. [CrossRef]

16. Cisek, A.A.; Dabrowska, I.; Gregorczyk, K.P.; Wyżewski, Z. Phage Therapy in Bacterial Infections Treatment: One Hundred Years After the Discovery of Bacteriophages. Curr. Microbiol. 2017, 74, 277-283. [CrossRef] [PubMed]

17. Domingo-Calap, P.; Georgel, P.; Bahram, S. Back to the future: Bacteriophages as promising therapeutic tools. HLA 2016, 87, 133-140. [CrossRef]

18. Jamal, M.; Bukhari, S.M.A.U.S.; Andleeb, S.; Ali, M.; Raza, S.; Nawaz, M.A.; Hussain, T.; Rahman, S.u.; Shah, S.S.A. Bacteriophages: An overview of the control strategies against multiple bacterial infections in different fields. J. Basic Microbiol. 2019, 59, 123-133. [CrossRef]

19. Mackey, M.C.; Santillán, M.; Tyran-Kamińska, M.; Zeron, E.S. Simple Mathematical Models of Gene Regulatory Dynamics. In Lecture Notes on Mathematical Modelling in the Life Sciences; Springer: Berlin/Heidelberg, Germany, 2016; pp. 87-97. [CrossRef]

20. Hay, I.D.; Lithgow, T. Filamentous phages: Masters of a microbial sharing economy. EMBO Rep. $2019,20$. [CrossRef]

21. Van Belleghem, J.D.; Dabrowska, K.; Vaneechoutte, M.; Barr, J.J.; Bollyky, P.L. Interactions between bacteriophage, bacteria, and the mammalian immune system. Viruses 2019, 11, 10. [CrossRef]

22. Barderas, R.; Benito-Peña, E. The 2018 Nobel Prize in Chemistry: Phage display of peptides and antibodies. Anal. Bioanal. Chem. 2019. [CrossRef]

23. Ledsgaard, L.; Kilstrup, M.; Karatt-Vellatt, A.; McCafferty, J.; Laustsen, A.H. Basics of antibody phage display technology. Toxins 2018, 10, 236. [CrossRef] [PubMed]

24. Schiavone, M.; Fiume, G.; Caivano, A.; de Laurentiis, A.; Falcone, C.; Masci, F.F.; Iaccino, E.; Mimmi, S.; Palmieri, C.; Pisano, A.; et al. Design and characterization of a peptide mimotope of the HIV-1 gp120 bridging sheet. Int. J. Mol. Sci. 2012, 13, 5674-5699. [CrossRef] [PubMed]

25. Goracci, M.; Pignochino, Y.; Marchiò, S. Phage Display-Based Nanotechnology Applications in Cancer Immunotherapy. Molecules 2020, 25, 843. [CrossRef] [PubMed]

26. Iaccino, E.; Mimmi, S.; Dattilo, V.; Marino, F.; Candeloro, P.; Di Loria, A.; Marimpietri, D.; Pisano, A.; Albano, F.; Vecchio, E.; et al. Monitoring multiple myeloma by idiotype-specific peptide binders of tumor-derived exosomes. Mol. Cancer 2017, 16, 1-9. [CrossRef]

27. O'Sullivan, L.; Buttimer, C.; McAuliffe, O.; Bolton, D.; Coffey, A. Bacteriophage-based tools: Recent advances and novel applications. F1000Research 2016, 5, 2782. [CrossRef]

28. Mimmi, S.; Maisano, D.; Quinto, I.; Iaccino, E. Phage Display: An Overview in Context to Drug Discovery. Trends Pharmacol. Sci. 2019, 40, 87-91. [CrossRef]

29. Sokullu, E.; Abyaneh, H.S.; Gauthier, M.A. Plant/bacterial virus-based drug discovery, drug delivery, and therapeutics. Pharmaceutics 2019, 11, 211. [CrossRef]

30. Petrenko, V.A. Landscape phage: Evolution from phage display to nanobiotechnology. Viruses 2018, 10, 311. [CrossRef] 
31. Garg, P. Filamentous bacteriophage: A prospective platform for targeting drugs in phage-mediated cancer therapy. J. Cancer Res. Ther. 2019, 15, 1. [CrossRef]

32. Sunderland, K.S.; Yang, M.; Mao, C. Phage-Enabled Nanomedicine: From Probes to Therapeutics in Precision Medicine. Angew. Chem. Int. Ed. 2017, 56, 1964-1992. [CrossRef]

33. Newman, M.R.; Benoit, D.S.W. In Vivo Translation of Peptide-Targeted Drug Delivery Systems Discovered by Phage Display. Bioconjug. Chem. 2018, 29, 2161-2169. [CrossRef] [PubMed]

34. Lauster, D.; Klenk, S.; Ludwig, K.; Nojoumi, S.; Behren, S.; Adam, L.; Stadtmüller, M.; Saenger, S.; Zimmler, S.; Hönzke, K.; et al. Phage capsid nanoparticles with defined ligand arrangement block influenza virus entry. Nat. Nanotechnol. 2020, 15, 373-379. [CrossRef] [PubMed]

35. Naik, R.R.; Jones, S.E.; Murray, C.J.; McAuliffe, J.C.; Vaia, R.A.; Stone, M.O. Peptide templates for nanoparticle synthesis derived from polymerase chain reaction-driven phage display. Adv. Funct. Mater. 2004, 14, 25-30. [CrossRef]

36. Golec, P.; Karczewska-Golec, J.; Weggrzyn, G. Phage display-selected peptides for binding and synthesis of nanoparticles: $\mathrm{ZnO}$ as an example. Biotechnologia 2016, 97, 145-151. [CrossRef]

37. You, F.; Yin, G.; Pu, X.; Li, Y.; Hu, Y.; Huang, Z.; Liao, X.; Yao, Y.; Chen, X. Biopanning and characterization of peptides with $\mathrm{Fe} 3 \mathrm{O} 4$ nanoparticles-binding capability via phage display random peptide library technique. Colloids Surf. B Biointerfaces 2016, 141, 537-545. [CrossRef]

38. Rawlings, A.E.; Bramble, J.P.; Tang, A.A.S.; Somner, L.A.; Monnington, A.E.; Cooke, D.J.; McPherson, M.J.; Tomlinson, D.C.; Staniland, S.S. Phage display selected magnetite interacting Adhirons for shape controlled nanoparticle synthesis. Chem. Sci. 2015, 6, 5586-5594. [CrossRef]

39. Dong, J.; Liu, C.; Zhang, J.; Xin, Z.T.; Yang, G.; Gao, B.; Mao, C.Q.; Liu, N.L.; Wang, F.; Shao, N.S.; et al. Selection of novel nickel-binding peptides from flagella displayed secondary peptide library. Chem. Biol. Drug Des. 2006. [CrossRef]

40. Naik, R.R.; Brott, L.L.; Clarson, S.J.; Stone, M.O. Silica-Precipitating Peptides Isolated from a Combinatorial Phage Display Peptide Library. J. Nanosci. Nanotechnol. 2002. [CrossRef]

41. Dickerson, M.B.; Jones, S.E.; Cai, Y.; Ahmad, G.; Naik, R.R.; Kröger, N.; Sandhage, K.H. Identification and design of peptides for the rapid, high-yield formation of nanoparticulate $\mathrm{TiO} 2$ from aqueous solutions at room temperature. Chem. Mater. 2008. [CrossRef]

42. Lee, S.W.; Mao, C.; Flynn, C.E.; Belcher, A.M. Ordering of quantum dots, using genetically engineered viruses. Science 2002. [CrossRef]

43. Flynn, C.E.; Mao, C.; Hayhurst, A.; Williams, J.L.; Georgiou, G.; Iverson, B.; Belcher, A.M. Synthesis and organization of nanoscale II-VI semiconductor materials using evolved peptide specificity and viral capsid assembly. J. Mater. Chem. 2003. [CrossRef]

44. Curtis, S.B.; Hewitt, J.; MacGillivray, R.T.A.; Dunbar, W.S. Biomining with bacteriophage: Selectivity of displayed peptides for naturally occurring sphalerite and chalcopyrite. Biotechnol. Bioeng. 2009, 102, 644-650. [CrossRef] [PubMed]

45. Yang, T.; Zhang, X.X.; Yang, J.Y.; Wang, Y.T.; Chen, M.L. Screening arsenic(III)-binding peptide for colorimetric detection of arsenic(III) based on the peptide induced aggregation of gold nanoparticles. Talanta 2018, 177, 212-216. [CrossRef] [PubMed]

46. Chow, E.; Goading, J.J. Peptide modified electrodes as electrochemical metal ion sensors. Electroanalysis 2006, 18, 1437-1448. [CrossRef]

47. Liu, P.; Han, L.; Wang, F.; Petrenko, V.A.; Liu, A. Gold nanoprobe functionalized with specific fusion protein selection from phage display and its application in rapid, selective and sensitive colorimetric biosensing of Staphylococcus aureus. Biosens. Bioelectron. 2016, 82, 195-203. [CrossRef]

48. Chen, C.L.; Rosi, N.L. Peptide-based methods for the preparation of nanostructured inorganic materials. Angew. Chem. Int. Ed. 2010, 49, 1924-1942. [CrossRef]

49. Limo, M.J.; Sola-Rabada, A.; Boix, E.; Thota, V.; Westcott, Z.C.; Puddu, V.; Perry, C.C. Interactions between Metal Oxides and Biomolecules: From Fundamental Understanding to Applications. Chem. Rev. 2018, 118, 11118-11193. [CrossRef]

50. Petrenko, V.A. Autonomous self-navigating drug-delivery vehicles: From science fiction to reality. Ther. Deliv. 2017, 8, 1063-1075. [CrossRef] 
51. Karimi, M.; Mirshekari, H.; Moosavi Basri, S.M.; Bahrami, S.; Moghoofei, M.; Hamblin, M.R. Bacteriophages and phage-inspired nanocarriers for targeted delivery of therapeutic cargos. Adv. Drug Deliv. Rev. 2016, 106, 45-62. [CrossRef]

52. Ju, Z.; Sun, W. Drug delivery vectors based on filamentous bacteriophages and phage-mimetic nanoparticles. Drug Deliv. 2017, 24, 1898-1908. [CrossRef]

53. Pizarro-Bauerle, J.; Ando, H. Engineered Bacteriophages for Practical Applications. Biol. Pharm. Bull. 2020, 43, 240-249. [CrossRef]

54. Pires, D.P.; Cleto, S.; Sillankorva, S.; Azeredo, J.; Lu, T.K. Genetically Engineered Phages: A Review of Advances over the Last Decade. Microbiol. Mol. Biol. Rev. 2016, 80, 523-543. [CrossRef] [PubMed]

55. Bernard, J.M.L.; Francis, M.B. Chemical strategies for the covalent modification of filamentous phage. Front. Microbiol. 2014, 5, 1-7. [CrossRef] [PubMed]

56. Bárdy, P.; Pantůček, R.; Benešík, M.; Doškař, J. Genetically modified bacteriophages in applied microbiology. J. Appl. Microbiol. 2016, 121, 618-633. [CrossRef] [PubMed]

57. Hyman, P.; Denyes, J. Bacteriophages in Nanotechnology: History and Future; Springer: Berlin/Heidelberg, Germany, 2018; ISBN 9783319405988.

58. Merril, C.R.; Geier, M.R.; Petricciani, J.C. Bacterial virus gene expression in human cells. Nature 1971, 233, 398-400. [CrossRef]

59. Poul, M.A.; Marks, J.D. Targeted gene delivery to mammalian cells by filamentous bacteriophage. J. Mol. Biol. 1999, 288, 203-211. [CrossRef] [PubMed]

60. Vaks, L.; Benhar, I. In vivo characteristics of targeted drug-carrying filamentous bacteriophage nanomedicines. J. Nanobiotechnol. 2011, 9, 58. [CrossRef]

61. Stephanopoulos, N.; Tong, G.J.; Hsiao, S.C.; Francis, M.B. Dual-surface modified virus capsids for targeted delivery of photodynamic agents to cancer cells. ACS Nano 2010, 4, 6014-6020. [CrossRef]

62. Zhu, J.; Tao, P.; Mahalingam, M.; Sha, J.; Kilgore, P.; Chopra, A.K.; Rao, V. A prokaryotic-eukaryotic hybrid viral vector for delivery of large cargos of genes and proteins into human cells. Sci. Adv. 2019, 5, 1-15. [CrossRef]

63. Petrenko, V.A.; Bedi, D.; Gillespie, J.W.; Petrenko, V.A.; Ebner, A.; Leitner, M.; Hinterdorfer, P. Targeted delivery of siRNA into breast cancer cells via phage fusion proteins. Mol. Pharm. 2013, 10, 551-559. [CrossRef]

64. Yoo, M.K.; Kang, S.K.; Choi, J.H.; Park, I.K.; Na, H.S.; Lee, H.C.; Kim, E.B.; Lee, N.K.; Nah, J.W.; Choi, Y.J.; et al. Targeted delivery of chitosan nanoparticles to Peyer's patch using M cell-homing peptide selected by phage display technique. Biomaterials 2010, 31, 7738-7747. [CrossRef] [PubMed]

65. Li, J.; Feng, L.; Fan, L.; Zha, Y.; Guo, L.; Zhang, Q.; Chen, J.; Pang, Z.; Wang, Y.; Jiang, X.; et al. Targeting the brain with PEG-PLGA nanoparticles modified with phage-displayed peptides. Biomaterials 2011, 32, 4943-4950. [CrossRef] [PubMed]

66. Ma, K.; Wang, D.D.; Lin, Y.; Wang, J.; Petrenko, V.; Mao, C. Synergetic targeted delivery of sleeping-beauty transposon system to mesenchymal stem cells using LPD nanoparticles modified with a phage-displayed targeting peptide. Adv. Funct. Mater. 2013, 23, 1172-1181. [CrossRef] [PubMed]

67. Jin, P.; Sha, R.; Zhang, Y.; Liu, L.; Bian, Y.; Qian, J.; Qian, J.; Lin, J.; Ishimwe, N.; Hu, Y.; et al. Blood Circulation-Prolonging Peptides for Engineered Nanoparticles Identified via Phage Display. Nano Lett. 2019, 19, 1467-1478. [CrossRef]

68. Wang, F.; Liu, P.; Sun, L.; Li, C.; Petrenko, V.A.; Liu, A. Bio-mimetic nanostructure self-assembled from Au@Ag heterogeneous nanorods and phage fusion proteins for targeted tumor optical detection and photothermal therapy. Sci. Rep. 2014, 4. [CrossRef]

69. Peng, H.; Borg, R.E.; Dow, L.P.; Pruitt, B.L.; Chen, I.A. Controlled phage therapy by photothermal ablation of specific bacterial species using gold nanorods targeted by chimeric phages. Proc. Natl. Acad. Sci. USA 2020, 117, 1951-1961. [CrossRef]

70. Weckmann, A.; Egler, C. Utilization of bacteriophages as molecular label. J. Nanosci. Nanotechnol. 2008, 8, 3988-3989. [CrossRef]

71. Kim, B.; Kim, E.S.; Yoo, Y.J.; Bae, H.W.; Chung, I.Y.; Cho, Y.H. Phage-derived antibacterials: Harnessing the simplicity, plasticity, and diversity of phages. Viruses 2019, 11, 268. [CrossRef]

72. Sulakvelidze, A.; Alavidze, Z.; Morris, J.G., Jr. Bacteriophage Therapy. Antimicrob. Agents Chemother. 2001, 45, 649-659. [CrossRef] 
73. Hess, K.L.; Jewell, C.M. Phage display as a tool for vaccine and immunotherapy development. Bioeng. Transl. Med. 2020, 5, 1-15. [CrossRef]

74. Summers, W.C. The strange history of phage therapy. Bacteriophage 2012, 2, 130-133. [CrossRef] [PubMed]

75. Ventola, C.L. The antibiotic resistance crisis: Part 1: Causes and threats. Pharm. Ther. 2015, 40, $277-283$.

76. Ventola, C.L. The Antibiotic Resistance Crisis Part 2: Management Strategies and New Agents. Pharm. Ther. 2015, 40, 344-352.

77. Lin, D.M.; Koskella, B.; Lin, H.C. Phage therapy: An alternative to antibiotics in the age of multi-drug resistance. World J. Gastrointest. Pharmacol. Ther. 2017, 8, 162. [CrossRef]

78. Parfitt, T. Georgia: An unlikely stronghold for bacteriophage therapy. Lancet 2005, 365, 2166-2167. [CrossRef]

79. Abedon, S.T.; Kuhl, S.J.; Blasdel, B.G.; Kutter, E.M. Phage treatment of human infections. Bacteriophage 2011, 1, 66-85. [CrossRef]

80. McCallin, S.; Alam Sarker, S.; Barretto, C.; Sultana, S.; Berger, B.; Huq, S.; Krause, L.; Bibiloni, R.; Schmitt, B.; Reuteler, G.; et al. Safety analysis of a Russian phage cocktail: From MetaGenomic analysis to oral application in healthy human subjects. Virology 2013, 443, 187-196. [CrossRef]

81. Wright, A.; Hawkins, C.H.; Änggård, E.E.; Harper, D.R. A controlled clinical trial of a therapeutic bacteriophage preparation in chronic otitis due to antibiotic-resistant Pseudomonas aeruginosa; A preliminary report of efficacy. Clin. Otolaryngol. 2009, 34, 349-357. [CrossRef]

82. Speck, P.; Smithyman, A. Safety and efficacy of phage therapy via the intravenous route. FEMS Microbiol. Lett. 2015, 363, 1-5. [CrossRef]

83. Jault, P.; Leclerc, T.; Jennes, S.; Pirnay, J.P.; Que, Y.-A.; Resch, G.; Rousseau, A.F.; Ravat, F.; Carsin, H.; Le Floch, R.; et al. Efficacy and tolerability of a cocktail of bacteriophages to treat burn wounds infected by Pseudomonas aeruginosa (PhagoBurn): A randomised, controlled, double-blind phase 1/2 trial. Lancet Infect. Dis. 2018, 19, 35-45. [CrossRef]

84. Voelker, R. FDA Approves Bacteriophage Trial. JAMA 2019, 321, 638. [CrossRef] [PubMed]

85. Gordillo Altamirano, F.L.; Barr, J.J. Phage therapy in the postantibiotic era. Clin. Microbiol. Rev. 2019, 32, 1-25. [CrossRef] [PubMed]

86. Loc-Carrillo, C.; Abedon, S.T. Pros and cons of phage therapy. Bacteriophage 2011, 1, 111-114. [CrossRef]

87. Fernández, L.; Gutiérrez, D.; Rodríguez, A.; García, P. Application of bacteriophages in the agro-food sector: A long way toward approval. Front. Cell. Infect. Microbiol. 2018, 8, 1-5. [CrossRef]

88. Pujato, S.A.; Quiberoni, A.; Mercanti, D.J. Bacteriophages on dairy foods. J. Appl. Microbiol. 2019, 126, 14-30. [CrossRef] [PubMed]

89. Vonasek, E.L.; Choi, A.H.; Sanchez, J.; Nitin, N. Incorporating Phage Therapy into WPI Dip Coatings for Applications on Fresh Whole and Cut Fruit and Vegetable Surfaces. J. Food Sci. 2018, 83, 1871-1879. [CrossRef]

90. Cadieux, B.; Colavecchio, A.; Jeukens, J.; Freschi, L.; Emond-Rheault, J.G.; Kukavica-Ibrulj, I.; Levesque, R.C.; Bekal, S.; Chandler, J.C.; Coleman, S.M.; et al. Prophage induction reduces Shiga toxin producing Escherichia coli (STEC) and Salmonella enterica on tomatoes and spinach: A model study. Food Control 2018, 89, 250-259. [CrossRef]

91. Alves, D.; Marques, A.; Milho, C.; Costa, M.J.; Pastrana, L.M.; Cerqueira, M.A.; Sillankorva, S.M. Bacteriophage $\phi I B B-P F 7 A$ loaded on sodium alginate-based films to prevent microbial meat spoilage. Int. J. Food Microbiol. 2019, 291, 121-127. [CrossRef]

92. Huang, K.; Nitin, N. Edible bacteriophage based antimicrobial coating on fish feed for enhanced treatment of bacterial infections in aquaculture industry. Aquaculture 2019, 502, 18-25. [CrossRef]

93. Svircev, A.; Roach, D.; Castle, A. Framing the future with bacteriophages in agriculture. Viruses 2018, 10, 218. [CrossRef]

94. Schwarz, B.; Uchida, M.; Douglas, T. Biomedical and Catalytic Opportunities of Virus-Like Particles in Nanotechnology. Adv. Virus Res. 2017, 97, 1-60. [CrossRef] [PubMed]

95. Yang, S.H.; Chung, W.J.; McFarland, S.; Lee, S.W. Assembly of bacteriophage into functional materials. Chem. Rec. 2013, 13, 43-59. [CrossRef] [PubMed]

96. Sawada, T. Filamentous virus-based soft materials based on controlled assembly through liquid crystalline formation. Polym. J. 2017, 49, 639-647. [CrossRef]

97. Sawada, T.; Serizawa, T. Filamentous viruses as building blocks for hierarchical self-assembly toward functional soft materials. Bull. Chem. Soc. Jpn. 2018, 91, 455-466. [CrossRef] 
98. Hernández-Gordillo, A.; Campero, A.; Vera-Robles, L.I. Mesoporous TiO2 synthesis using a semi-hard biological template. Microporous Mesoporous Mater. 2018, 270, 140-148. [CrossRef]

99. Lee, J.H.; Lee, J.H.; Xiao, J.; Desai, M.S.; Zhang, X.; Lee, S.W. Vertical Self-Assembly of Polarized Phage Nanostructure for Energy Harvesting. Nano Lett. 2019, 19, 2661-2667. [CrossRef]

100. Lee, B.Y.; Zhang, J.; Zueger, C.; Chung, W.-J.J.; Yoo, S.Y.; Wang, E.; Meyer, J.; Ramesh, R.; Lee, S.-W.W. Virus-based piezoelectric energy generation. Nat. Nanotechnol. 2012, 7, 351-356. [CrossRef]

101. Records, W.C.; Wei, S.; Belcher, A.M. Virus-Templated Nickel Phosphide Nanofoams as Additive-Free, Thin-Film Li-Ion Microbattery Anodes. Small 2019, 15, 1-9. [CrossRef]

102. Rosant, C.; Avalle, B.; Larcher, D.; Dupont, L.; Friboulet, A.; Tarascon, J.M. Biosynthesis of Co3O4 electrode materials by peptide and phage engineering: Comprehension and future. Energy Environ. Sci. 2012, 5, 9936-9943. [CrossRef]

103. Jończyk, E.; Kłak, M.; Międzybrodzki, R.; Górski, A. The influence of external factors on bacteriophages-review. Folia Microbiol. (Praha) 2011, 56, 191-200. [CrossRef]

104. Jończyk-Matysiak, E.; Weber-Dąbrowska, B.; Owczarek, B.; Międzybrodzki, R.; Łusiak-Szelachowska, M.; Łodej, N.; Górski, A. Phage-Phagocyte Interactions and Their Implications for Phage Application as Therapeutics. Viruses 2017, 9, 150. [CrossRef] [PubMed]

105. Richter, Ł.; Matuła, K.; Leśniewski, A.; Kwaśnicka, K.; Łoś, J.; Łoś, M.; Paczesny, J.; Hołyst, R. Ordering of bacteriophages in the electric field: Application for bacteria detection. Sens. Actuators B Chem. 2016, 224, 233-240. [CrossRef]

106. Richter, Ł.; Bielec, K.; Leśniewski, A.; Łoś, M.; Paczesny, J.; Hołyst, R. Dense Layer of Bacteriophages Ordered in Alternating Electric Field and Immobilized by Surface Chemical Modification as Sensing Element for Bacteria Detection. ACS Appl. Mater. Interfaces 2017, 9, 19622-19629. [CrossRef] [PubMed]

107. White, H.E.; Sherman, M.B.; Brasiles, S.; Jacquet, E.; Seavers, P.; Tavares, P.; Orlova, E.V. Capsid Structure and Its Stability at the Late Stages of Bacteriophage SPP1 Assembly. J. Virol. 2012. [CrossRef] [PubMed]

108. Bauer, D.W.; Li, D.; Huffman, J.; Homa, F.L.; Wilson, K.; Leavitt, J.C.; Casjens, S.R.; Baines, J.; Evilevitch, A. Exploring the Balance between DNA Pressure and Capsid Stability in Herpesviruses and Phages. J. Virol. 2015. [CrossRef]

109. Janczuk, M.; Richter, Ł.; Hoser, G.; Kawiak, J.; Łoś, M.; Niedziółka-Jönsson, J.; Paczesny, J.; Hołyst, R. Bacteriophage-Based Bioconjugates as a Flow Cytometry Probe for Fast Bacteria Detection. Bioconjug. Chem. 2017, 28, 419-425. [CrossRef]

110. Farr, R.; Choi, D.S.; Lee, S.W. Phage-based nanomaterials for biomedical applications. Acta Biomater. 2014, 10, 1741-1750. [CrossRef]

111. Lee, T.J.; Schwartz, C.; Guo, P. Construction of bacteriophage Phi29 DNA packaging motor and its applications in nanotechnology and therapy. Ann. Biomed. Eng. 2009, 37, 2064-2081. [CrossRef]

112. Yoo, Y.J.; Kim, W.G.; Ko, J.H.; Kim, Y.J.; Lee, Y.; Stanciu, S.G.; Lee, J.M.; Kim, S.; Oh, J.W.; Song, Y.M. Large-Area Virus Coated Ultrathin Colorimetric Sensors with a Highly Lossy Resonant Promoter for Enhanced Chromaticity. Adv. Sci. 2020, 2020, 2000978. [CrossRef]

113. Lee, J.Y.; Chung, W.J.; Kim, G. A mechanically improved virus-based hybrid scaffold for bone tissue regeneration. RSC Adv. 2016, 6, 55022-55032. [CrossRef]

114. Hosseinidoust, Z.; Olsson, A.L.J.; Tufenkji, N. Going viral: Designing bioactive surfaces with bacteriophage. Colloids Surf. B Biointerfaces 2014, 124, 2-16. [CrossRef] [PubMed]

115. Nogueira, F.; Karumidze, N.; Kusradze, I.; Goderdzishvili, M.; Teixeira, P.; Gouveia, I.C. Immobilization of bacteriophage in wound-dressing nanostructure. Nanomed. Nanotechnol. Biol. Med. 2017, 13, 2475-2484. [CrossRef]

116. Anany, H.; Chen, W.; Pelton, R.; Griffiths, M.W. Biocontrol of Listeria monocytogenes and Escherichia coli O157:H7 in meat by using phages immobilized on modified cellulose membranes. Appl. Environ. Microbiol. 2011, 77, 6379-6387. [CrossRef] [PubMed]

117. Lone, A.; Anany, H.; Hakeem, M.; Aguis, L.; Avdjian, A.C.; Bouget, M.; Atashi, A.; Brovko, L.; Rochefort, D.; Griffiths, M.W. Development of prototypes of bioactive packaging materials based on immobilized bacteriophages for control of growth of bacterial pathogens in foods. Int. J. Food Microbiol. 2016, 217, 49-58. [CrossRef]

118. Wu, B.; Wang, R.; Fane, A.G. The roles of bacteriophages in membrane-based water and wastewater treatment processes: A review. Water Res. 2017, 110, 120-132. [CrossRef] 
119. Kimmelshue, C.; Goggi, A.S.; Cademartiri, R. The use of biological seed coatings based on bacteriophages and polymers against Clavibacter michiganensis subsp. nebraskensis in maize seeds. Sci. Rep. 2019, 9, 1-11. [CrossRef] [PubMed]

120. Kim, S.; Jo, A.; Ahn, J. Application of chitosan-alginate microspheres for the sustained release of bacteriophage in simulated gastrointestinal conditions. Int. J. Food Sci. Technol. 2015, 50, 913-918. [CrossRef]

121. Yongsheng, M.; Pacan, J.C.; Wang, Q.; Xu, Y.; Huang, X.; Korenevsky, A.; Sabour, P.M. Microencapsulation of bacteriophage felix o1 into chitosan-alginate microspheres for oral delivery. Appl. Environ. Microbiol. 2008, 74, 4799-4805. [CrossRef]

122. Cheng, W.; Zhang, Z.; Xu, R.; Cai, P.; Kristensen, P.; Chen, M.; Huang, Y. Incorporation of bacteriophages in polycaprolactone/collagen fibers for antibacterial hemostatic dual-function. J. Biomed. Mater. Res. Part B Appl. Biomater. 2018, 106, 2588-2595. [CrossRef]

123. Korehei, R.; Kadla, J. Incorporation of T4 bacteriophage in electrospun fibres. J. Appl. Microbiol. 2013, 114, 1425-1434. [CrossRef]

124. Tomat, D.; Soazo, M.; Verdini, R.; Casabonne, C.; Aquili, V.; Balagué, C.; Quiberoni, A. Evaluation of an WPC edible film added with a cocktail of six lytic phages against foodborne pathogens such as enteropathogenic and Shigatoxigenic Escherichia coli. LWT 2019, 113, 108316. [CrossRef]

125. Amarillas, L.; Lightbourn-Rojas, L.; Angulo-Gaxiola, A.K.; Basilio Heredia, J.; González-Robles, A.; León-Félix, J. The antibacterial effect of chitosan-based edible coating incorporated with a lytic bacteriophage against Escherichia coli O157:H7 on the surface of tomatoes. J. Food Saf. 2018, 38, 1-10. [CrossRef]

126. Leppänen, M.; Maasilta, I.J.; Sundberg, L.R. Antibacterial Efficiency of Surface-Immobilized Flavobacterium-Infecting Bacteriophage. ACS Appl. Bio Mater. 2019, 2, 4720-4727. [CrossRef]

127. Ahiwale, S.S.; Bankar, A.V.; Tagunde, S.; Kapadnis, B.P. A Bacteriophage Mediated Gold Nanoparticles Synthesis and Their Anti-biofilm Activity. Indian J. Microbiol. 2017, 57, 188-194. [CrossRef] [PubMed]

128. Hopf, J.; Waters, M.; Kalwajtys, V.; Carothers, K.E.; Roeder, R.K.; Shrout, J.D.; Lee, S.W.; Nallathamby, P.D. Phage-mimicking antibacterial core-shell nanoparticles. Nanoscale Adv. 2019, 1, 4812-4826. [CrossRef]

129. Tolba, M.; Minikh, O.; Brovko, L.Y.; Evoy, S.; Griffiths, M.W. Oriented immobilization of bacteriophages for biosensor applications. Appl. Environ. Microbiol. 2010, 76, 528-535. [CrossRef]

130. Meyer, A.; Greene, M.; Kimmelshue, C.; Cademartiri, R. Stabilization of T4 bacteriophage at acidic and basic pH by adsorption on paper. Colloids Surf. B Biointerfaces 2017, 160, 169-176. [CrossRef] [PubMed]

131. Leung, V.; Szewczyk, A.; Chau, J.; Hosseinidoust, Z.; Groves, L.; Hawsawi, H.; Anany, H.; Griffiths, M.W.; Monsur Ali, M.; Filipe, C.D.M. Long-Term Preservation of Bacteriophage Antimicrobials Using Sugar Glasses. ACS Biomater. Sci. Eng. 2018, 4, 3802-3808. [CrossRef]

132. Leung, V.; Groves, L.; Szewczyk, A.; Hosseinidoust, Z.; Filipe, C.D.M. Long-Term Antimicrobial Activity of Phage-Sugar Glasses is Closely Tied to the Processing Conditions. ACS Omega 2018, 3, 18295-18303. [CrossRef]

133. Paczesny, J.; Richter, Ł.; Hołyst, R. Recent Progress in the Detection of Bacteria Using Bacteriophages: A Review. Viruses 2020, 12, 845. [CrossRef]

134. Richter, Ł.; Janczuk-Richter, M.; Niedziółka-Jönsson, J.; Paczesny, J.; Hołyst, R. Recent advances in bacteriophage-based methods for bacteria detection. Drug Discov. Today 2018, 23, 448-455. [CrossRef] [PubMed]

135. Machera, S.J.; Niedziółka-Jönsson, J.; Szot-Karpińska, K. Phage-Based Sensors in Medicine: A Review. Chemosensors 2020, 8, 61. [CrossRef]

136. Farooq, U.; Yang, Q.; Ullah, M.W.; Wang, S. Bacterial biosensing: Recent advances in phage-based bioassays and biosensors. Biosens. Bioelectron. 2018, 118, 204-216. [CrossRef] [PubMed]

137. Farooq, U.; Yang, Q.; Wajid Ullah, M.; Wang, S. Principle and Development of Phage-Based Biosensors. Biosens. Environ. Monit. 2019. [CrossRef]

138. Opota, O.; Jaton, K.; Greub, G. Microbial diagnosis of bloodstream infection: Towards molecular diagnosis directly from blood. Clin. Microbiol. Infect. 2015, 21, 323-331. [CrossRef]

139. Alam, N.; Oskam, E.; Stassen, P.M.; van Exter, P.; van de Ven, P.M.; Haak, H.R.; Holleman, F.; van Zanten, A.; van Leeuwen-Nguyen, H.; Bon, V.; et al. Prehospital antibiotics in the ambulance for sepsis: A multicentre, open label, randomised trial. Lancet Respir. Med. 2018, 6, 40-50. [CrossRef] 
140. Hinkley, T.C.; Garing, S.; Jain, P.; Williford, J.; Le Ny, A.-L.M.; Nichols, K.P.; Peters, J.E.; Talbert, J.N.; Nugen, S.R. A Syringe-Based Biosensor to Rapidly Detect Low Levels of Escherichia Coli (ECOR13) in Drinking Water Using Engineered Bacteriophages. Sensors 2020, 20, 1953. [CrossRef]

141. Farooq, U.; Ullah, M.W.; Yang, Q.; Aziz, A.; Xu, J.; Zhou, L.; Wang, S. High-density phage particles immobilization in surface-modified bacterial cellulose for ultra-sensitive and selective electrochemical detection of Staphylococcus aureus. Biosens. Bioelectron. 2020, 157, 112163. [CrossRef]

142. Xu, J.; Zhao, C.; Chau, Y.; Lee, Y.K. The synergy of chemical immobilization and electrical orientation of T4 bacteriophage on a micro electrochemical sensor for low-level viable bacteria detection via Differential Pulse Voltammetry. Biosens. Bioelectron. 2020, 151, 111914. [CrossRef]

143. Sedki, M.; Chen, X.; Chen, C.; Ge, X.; Mulchandani, A. Non-lytic M13 phage-based highly sensitive impedimetric cytosensor for detection of coliforms. Biosens. Bioelectron. 2020, 148, 111794. [CrossRef]

144. Yue, H.; He, Y.; Fan, E.; Wang, L.; Lu, S.; Fu, Z. Label-free electrochemiluminescent biosensor for rapid and sensitive detection of pseudomonas aeruginosa using phage as highly specific recognition agent. Biosens. Bioelectron. 2017, 94, 429-432. [CrossRef] [PubMed]

145. He, Y.; Shi, Y.; Liu, M.; Wang, Y.; Wang, L.; Lu, S.; Fu, Z. Nonlytic Recombinant Phage Tail Fiber Protein for Specific Recognition of Pseudomonas aeruginosa. Anal. Chem. 2018, 90, 14462-14468. [CrossRef] [PubMed]

146. Wang, Y.; He, Y.; Bhattacharyya, S.; Lu, S.; Fu, Z. Recombinant Bacteriophage Cell-Binding Domain Proteins for Broad-Spectrum Recognition of Methicillin-Resistant Staphylococcus aureus Strains. Anal. Chem. 2020, 92, 3340-3345. [CrossRef] [PubMed]

147. Neufeld, T.; Schwartz-Mittelmann, A.; Biran, D.; Ron, E.Z.; Rishpon, J. Combined phage typing and amperometric detection of released enzymatic activity for the specific identification and quantification of bacteria. Anal. Chem. 2003, 75, 580-585. [CrossRef]

148. Hinkley, T.C.; Singh, S.; Garing, S.; Le Ny, A.L.M.; Nichols, K.P.; Peters, J.E.; Talbert, J.N.; Nugen, S.R. A phage-based assay for the rapid, quantitative, and single CFU visualization of E. coli (ECOR \#13) in drinking water. Sci. Rep. 2018, 8, 1-8. [CrossRef]

149. Anany, H.; Brovko, L.; El Dougdoug, N.K.; Sohar, J.; Fenn, H.; Alasiri, N.; Jabrane, T.; Mangin, P.; Monsur Ali, M.; Kannan, B.; et al. Print to detect: A rapid and ultrasensitive phage-based dipstick assay for foodborne pathogens. Anal. Bioanal. Chem. 2018, 410, 1217-1230. [CrossRef]

150. Laube, T.; Cortés, P.; Llagostera, M.; Alegret, S.; Pividori, M.I. Phagomagnetic immunoassay for the rapid detection of Salmonella. Appl. Microbiol. Biotechnol. 2014, 98, 1795-1805. [CrossRef]

151. Armon, R.; Kott, Y. Bacteriophages as indicators of pollution. Crit. Rev. Environ. Sci. Technol. 1996, 26, $299-335$. [CrossRef]

152. Kim, C.; Lee, H.; Devaraj, V.; Kim, W.G.; Lee, Y.; Kim, Y.; Jeong, N.N.; Choi, E.J.; Baek, S.H.; Han, D.W.; et al. Hierarchical cluster analysis of medical chemicals detected by a bacteriophage-based colorimetric sensor array. Nanomaterials 2020, 10, 121. [CrossRef]

153. Cao, B.; Li, Y.; Yang, T.; Bao, Q.; Yang, M.; Mao, C. Bacteriophage-based biomaterials for tissue regeneration. Adv. Drug Deliv. Rev. 2019, 145, 73-95. [CrossRef]

154. Alvarez, L.; Lettinga, M.P.; Grelet, E. Fast Diffusion of Long Guest Rods in a Lamellar Phase of Short Host Particles. Phys. Rev. Lett. 2017, 118, 1-5. [CrossRef] [PubMed]

155. Janczuk, M.; Niedziółka-Jönsson, J.; Szot-Karpińska, K. Bacteriophages in electrochemistry: A review. J. Electroanal. Chem. 2016, 779, 207-219. [CrossRef]

156. Chen, P.Y.; Dang, X.; Klug, M.T.; Qi, J.; Dorval Courchesne, N.M.; Burpo, F.J.; Fang, N.; Hammond, P.T.; Belcher, A.M. Versatile three-dimensional virus-based template for dye-sensitized solar cells with improved electron transport and light harvesting. ACS Nano 2013, 7, 6563-6574. [CrossRef]

157. Dogic, Z. Filamentous Phages As a Model System in Soft Matter Physics. Front. Microbiol. 2016, 7. [CrossRef]

158. Raja, I.S.; Kim, C.; Song, S.J.; Shin, Y.C.; Kang, M.S.; Hyon, S.H.; Oh, J.W.; Han, D.W. Virus-incorporated biomimetic nanocomposites for tissue regeneration. Nanomaterials 2019, 9, 1014. [CrossRef] [PubMed]

159. Wang, J.; Yang, M.; Zhu, Y.; Wang, L.; Tomsia, A.P.; Mao, C. Phage nanofibers induce vascularized osteogenesis in $3 \mathrm{D}$ printed bone scaffolds. Adv. Mater. 2014. [CrossRef]

160. Deng, Q.; Cai, W.; Li, S.; Su, B. Identification of a NEP1-35 recognizing peptide that neutralizes CNS myelin inhibition using phage display library. Neurosci. Lett. 2013, 536, 80-84. [CrossRef]

161. Lee, D.Y.; Lee, H.; Kim, Y.; Yoo, S.Y.; Chung, W.J.; Kim, G. Phage as versatile nanoink for printing 3-D cell-laden scaffolds. Acta Biomater. 2016, 29, 112-124. [CrossRef] 
162. Pi, Y.; Zhang, X.; Shi, J.; Zhu, J.; Chen, W.; Zhang, C.; Gao, W.; Zhou, C.; Ao, Y. Targeted delivery of non-viral vectors to cartilage in vivo using a chondrocyte-homing peptide identified by phage display. Biomaterials 2011, 32, 6324-6332. [CrossRef]

163. Wang, F.; Cao, B.; Mao, C. Bacteriophage bundles with prealigned $\mathrm{Ca}^{2+}$ Initiate the oriented nucleation and growth of hydroxylapatite. Chem. Mater. 2010. [CrossRef]

164. Xu, X.; Fang, X.; Zhai, T.; Zeng, H.; Liu, B.; Hu, X.; Bando, Y.; Golberg, D. Tube-in-tube TiO2 nanotubes with porous walls: Fabrication, formation mechanism, and photocatalytic properties. Small 2011, 7, 445-449. [CrossRef] [PubMed]

165. Zhao, W.; Yuan, H.; Xu, X.; Ma, L. Isolation and initial application of a novel peptide that specifically recognizes the neural stem cells derived from rhesus monkey embryonic stem cells. J. Biomol. Screen. 2010, 15, 687-694. [CrossRef] [PubMed]

166. Bakhshinejad, B.; Sadeghizadeh, M. Bacteriophages and development of nanomaterials for neural regeneration. Neural Regen. Res. 2014, 9, 1955-1958. [CrossRef]

167. Kamińska, A.; Szymborski, T.; Witkowska, E.; Kijeńska-Gawrońska, E.; Świeszkowski, W.; Niciński, K.; Trzcińska-Danielewicz, J.; Girstun, A. Detection of circulating tumor cells using membrane-based sers platform: A new diagnostic approach for 'liquid biopsy'. Nanomaterials 2019, 9, 366. [CrossRef]

168. Richter, Ł.; Albrycht, P.; Księżopolska-Gocalska, M.; Poboży, E.; Bachliński, R.; Sashuk, V.; Paczesny, J.; Hołyst, R. Fast and efficient deposition of broad range of analytes on substrates for surface enhanced Raman spectroscopy. Biosens. Bioelectron. 2020, 156. [CrossRef]

169. Palásti, D.J.; Albrycht, P.; Janovszky, P.; Paszkowska, K.; Geretovszky, Z.; Galbács, G. Nanoparticle enhanced laser induced breakdown spectroscopy of liquid samples by using modified surface-enhanced Raman scattering substrates. Spectrochim. Acta Part B At. Spectrosc. 2020. [CrossRef]

170. Koh, E.H.; Mun, C.; Kim, C.; Park, S.G.; Choi, E.J.; Kim, S.H.; Dang, J.; Choo, J.; Oh, J.W.; Kim, D.H.; et al. M13 Bacteriophage/Silver Nanowire Surface-Enhanced Raman Scattering Sensor for Sensitive and Selective Pesticide Detection. ACS Appl. Mater. Interfaces 2018, 10, 10388-10397. [CrossRef]

171. Nam, K.T.; Kim, D.; Yoo, P.J.; Chiang, C.; Meethong, N.; Hammond, P.T.; Chiang, Y.; Belcher, A.M. Virus-Enabled Synthesis and Assembly Battery Electrodes. Science 2006, 885-888. [CrossRef]

172. Vera-Robles, L.I.; Van Tran Nhieu, G.; Laberty-Robert, C.; Livage, J.; Sanchez, C. Flexible electroactive nanomaterials biotemplated with versatile m13 phage platforms. Adv. Eng. Mater. 2013, 15, 954-961. [CrossRef]

173. Dong, D.; Zhang, Y.; Sutaria, S.; Konarov, A.; Chen, P. Binding mechanism and electrochemical properties of M13 phage-sulfur composite. PLoS One 2013, 8, e82332. [CrossRef]

174. Moradi, M.; Li, Z.; Qi, J.; Xing, W.; Xiang, K.; Chiang, Y.M.; Belcher, A.M. Improving the capacity of sodium ion battery using a virus-templated nanostructured composite cathode. Nano Lett. 2015, 15, 2917-2921. [CrossRef]

175. Nguyen, V.; Zhu, R.; Jenkins, K.; Yang, R. Self-assembly of diphenylalanine peptide with controlled polarization for power generation. Nat. Commun. 2016, 7, 1-6. [CrossRef]

176. Lin, H.S.; Lee, J.M.; Han, J.; Lee, C.; Seo, S.; Tan, S.; Lee, H.M.; Choi, E.J.; Strano, M.S.; Yang, Y.; et al. Denatured M13 Bacteriophage-Templated Perovskite Solar Cells Exhibiting High Efficiency. Adv. Sci. 2020, 2020, 2000782. [CrossRef]

177. Lee, H.B.; Kim, W.G.; Lee, M.; Lee, J.M.; He, S.; Kumar, N.; Devaraj, V.; Choi, E.J.; Jeon, I.; Song, M.; et al. Gap Plasmon of Virus-Templated Biohybrid Nanostructures Uplifting the Performance of Organic Optoelectronic Devices. Adv. Opt. Mater. 2020, 8, 1-8. [CrossRef]

178. Lee, Y.; Kim, J.; Yun, D.S.; Nam, Y.S.; Shao-Horn, Y.; Belcher, A.M. Virus-templated Au and Au-Pt core-shell nanowires and their electrocatalytic activities for fuel cell applications. Energy Environ. Sci. 2012, 5, 8328. [CrossRef]

179. Blaik, R.A.; Lan, E.; Huang, Y.; Dunn, B. Gold-coated M13 bacteriophage as a template for glucose oxidase biofuel cells with direct electron transfer. ACS Nano 2016, 10, 324-332. [CrossRef] [PubMed]

180. Dorval Courchesne, N.M.; Klug, M.T.; Huang, K.J.; Weidman, M.C.; Cantú, V.J.; Chen, P.Y.; Kooi, S.E.; Yun, D.S.; Tisdale, W.A.; Fang, N.X.; et al. Constructing Multifunctional Virus-Templated Nanoporous Composites for Thin Film Solar Cells: Contributions of Morphology and Optics to Photocurrent Generation. J. Phys. Chem. C 2015, 119, 13987-14000. [CrossRef] 
181. Fadel, A.; Hala, M.; Nashwa, A.; Hanan, M.; Hamida, H. Control the activity of Rift Valley Fever Virus by Electric Field waves at resonance frequency (In vivo \&In vitro) studies. IOSR J. Appl. Phys. 2014, 6, 07-17.

182. Dogic, Z.; Fraden, S. Ordered phases of filamentous viruses. Curr. Opin. Colloid Interface Sci. 2006, 11, 47-55. [CrossRef]

183. Yoo, P.J.; Nam, K.T.; Qi, J.; Lee, S.K.; Park, J.; Belcher, A.M.; Hammond, P.T. Spontaneous assembly of viruses on multilayered polymer surfaces. Nat. Mater. 2006, 5, 234-240. [CrossRef]

184. Špakova, A.; Šimoliūnas, E.; Batiuškaitè, R.; Pajeda, S.; Meškys, R.; Petraitytė-Burneikienė, R. Self-assembly of tail tube protein of bacteriophage vB_EcoS_NBD2 into extremely long polytubes in E. Coli and S. cerevisiae. Viruses 2019, 11, 208. [CrossRef]

185. Einstein, A. Über die von der molekularkinetischen Theorie der Wärme geforderte Bewegung von in ruhenden Flüssigkeiten suspendierten Teilchen. Ann. Phys. 1905. [CrossRef]

186. Von Smoluchowski, M. Zur kinetischen Theorie der Brown'schen Molekularbewegungen und der Suspensionen-Smoluchowski, M. v., (Ann. d. Physik 21, 756-80.). Z. Chem. Ind. Kolloide 1907, 1, 308-309. [CrossRef]

187. Höfling, F.; Franosch, T. Anomalous transport in the crowded world of biological cells. Rep. Prog. Phys. 2013, 76, 1-55. [CrossRef]

188. Kalwarczyk, T.; Sozanski, K.; Ochab-Marcinek, A.; Szymanski, J.; Tabaka, M.; Hou, S.; Holyst, R. Motion of nanoprobes in complex liquids within the framework of the length-scale dependent viscosity model. Adv. Colloid Interface Sci. 2015, 223, 55-63. [CrossRef]

189. Holmqvist, P.; Kleshchanok, D.; Lang, P.R. Interaction potential and near wall dynamics of spherical colloids in suspensions of rod-like fd-virus. Eur. Phys. J. E 2008, 26, 177-182. [CrossRef] [PubMed]

190. Kang, K.; Gapinski, J.; Lettinga, M.P.; Buitenhuis, J.; Meier, G.; Ratajczyk, M.; Dhont, J.K.G.; Patkowski, A. Diffusion of spheres in crowded suspensions of rods. J. Chem. Phys. 2005, 122. [CrossRef] [PubMed]

191. Lettinga, M.P.; Dhont, J.K.G.; Zhang, Z.; Messlinger, S.; Gompper, G. Hydrodynamic interactions in rod suspensions with orientational ordering. Soft Matter 2010, 6, 4556-4562. [CrossRef]

192. Kang, K.; Wilk, A.; Buitenhuis, J.; Patkowski, A.; Dhont, J.K.G. Diffusion of spheres in isotropic and nematic suspensions of rods. J. Chem. Phys. 2006, 124, 1-17. [CrossRef]

193. Kang, K.; Wilk, A.; Patkowski, A.; Dhont, J.K.G. Diffusion of spheres in isotropic and nematic networks of rods: Electrostatic interactions and hydrodynamic screening. J. Chem. Phys. 2007, 126, 1-17. [CrossRef]

194. Barabé, B.; Abakumov, S.; Gunes, D.Z.; Lettinga, M.P. Sedimentation of large particles in a suspension of colloidal rods. Phys. Fluids 2020, 32, 053105. [CrossRef]

195. Secor, P.R.; Burgener, E.B.; Kinnersley, M.; Jennings, L.K.; Roman-Cruz, V.; Popescu, M.; Van Belleghem, J.D.; Haddock, N.; Copeland, C.; Michaels, L.A.; et al. Pf Bacteriophage and Their Impact on Pseudomonas Virulence, Mammalian Immunity, and Chronic Infections. Front. Immunol. 2020, 11, 1-18. [CrossRef]

196. Burgener, E.B.; Sweere, J.M.; Bach, M.S.; Secor, P.R.; Haddock, N.; Jennings, L.K.; Marvig, R.L.; Johansen, H.K.; Rossi, E.; Cao, X.; et al. Filamentous bacteriophages are associated with chronic Pseudomonas lung infections and antibiotic resistance in cystic fibrosis. Sci. Transl. Med. 2019, 11, 1-12. [CrossRef] [PubMed]

197. Secor, P.R.; Jennings, L.K.; Michaels, L.A.; Sweere, J.M.; Singh, P.K.; Parks, W.C.; Bollyky, P.L. Biofilm assembly becomes crystal clear-Filamentous bacteriophage organize the Pseudomonas aeruginosa biofilm matrix into a liquid crystal. Microb. Cell 2016, 3, 49-52. [CrossRef] [PubMed]

198. Liu, S.; Zheng, C.; Ye, Z.; Blanc, B.; Zhi, X.; Shi, L.; Zhang, Z. Filamentous Viruses Grafted with Thermoresponsive Block Polymers: Liquid Crystal Behaviors of a Rodlike Colloidal Model with "true" Attractive Interactions. Macromolecules 2018, 51, 8013-8026. [CrossRef]

199. Zhang, Z.; Krishna, N.; Lettinga, M.P.; Vermant, J.; Grelet, E. Reversible gelation of rod-like viruses grafted with thermoresponsive polymers. Langmuir 2009, 25, 2437-2442. [CrossRef]

200. Jończyk-Matysiak, E.; Łodej, N.; Kula, D.; Owczarek, B.; Orwat, F.; Międzybrodzki, R.; Neuberg, J.; Bagińska, N.; Weber-Dabrowska, B.; Górski, A. Factors determining phage stability/activity: Challenges in practical phage application. Expert Rev. Anti. Infect. Ther. 2019, 17, 583-606. [CrossRef]

201. Golec, P.; Dabrowski Kamil, K.; Hejnowicz, M.S.; Gozdek, A.; Łoś, J.M.; Wegrzyn, G.; Łobocka, M.B.; Łoś, M. A reliable method for storage of tailed phages. J. Microbiol. Methods 2011, 84, 486-489. [CrossRef]

202. Malik, D.J.; Sokolov, I.J.; Vinner, G.K.; Mancuso, F.; Cinquerrui, S.; Vladisavljevic, G.T.; Clokie, M.R.J.; Garton, N.J.; Stapley, A.G.F.; Kirpichnikova, A. Formulation, stabilisation and encapsulation of bacteriophage for phage therapy. Adv. Colloid Interface Sci. 2017, 249, 100-133. [CrossRef] 
203. Gonzalez-Menendez, E.; Fernandez, L.; Gutierrez, D.; Rodríguez, A.; Martínez, B.; GarcíaI, P. Comparative analysis of different preservation techniques for the storage of Staphylococcus phages aimed for the industrial development of phage-based antimicrobial products. PLOS ONE 2018, 13, e0205728. [CrossRef]

204. Wolfson, L.J.; Gasse, F.; Lee-Martin, S.P.; Lydon, P.; Magan, A.; Tibouti, A.; Johns, B.; Hutubessy, R.; Salama, P.; Okwo-Bele, J.M. Estimating the costs of achieving the WHO-UNICEF Global Immunization Vision and Strategy, 2006-2015. Bull. World Health Organ. 2008, 86, 27-39. [CrossRef] [PubMed]

205. Croyle, M.A.; Cheng, X.; Wilson, J.M. Development of formulations that enhance physical stability of viral vectors for gene therapy. Gene Ther. 2001. [CrossRef]

206. Evans, R.K.; Nawrocki, D.K.; Isopi, L.A.; Williams, D.M.; Casimiro, D.R.; Chin, S.; Chen, M.; Zhu, D.M.; Shiver, J.W.; Volkin, D.B. Development of stable liquid formulations for adenovirus-based vaccines. J. Pharm. Sci. 2004. [CrossRef] [PubMed]

207. Rexroad, J.; Wiethoff, C.M.; Green, A.P.; Kierstead, T.D.; Scott, M.O.; Middaugh, C.R. Structural stability of adenovirus type 5. J. Pharm. Sci. 2003. [CrossRef] [PubMed]

208. Stewart, M.; Ward, S.J.; Drew, J. Use of adenovirus as a model system to illustrate a simple method using standard equipment and inexpensive excipients to remove live virus dependence on the cold-chain. Vaccine 2014. [CrossRef]

209. Pelliccia, M.; Andreozzi, P.; Paulose, J.; D’Alicarnasso, M.; Cagno, V.; Donalisio, M.; Civra, A.; Broeckel, R.M.; Haese, N.; Jacob Silva, P.; et al. Additives for vaccine storage to improve thermal stability of adenoviruses from hours to months. Nat. Commun. 2016, 7, 13520. [CrossRef]

210. Fernández, L.; Escobedo, S.; Gutiérrez, D.; Portilla, S.; Martínez, B.; García, P.; Rodríguez, A. Bacteriophages in the dairy environment: From enemies to allies. Antibiotics 2017, 6, 27. [CrossRef]

211. Richter, Ł.; Paszkowska, K.; Cendrowska, U.; Olgiati, F.; Silva, P.J.; Gasbarri, M.; Guven, Z.P.; Paczesny, J.; Stellacci, F. Broad-spectrum Nanoparticles against Bacteriophage Infections. 2020, submitted.

(C) 2020 by the authors. Licensee MDPI, Basel, Switzerland. This article is an open access article distributed under the terms and conditions of the Creative Commons Attribution (CC BY) license (http://creativecommons.org/licenses/by/4.0/). 